\title{
Plutonium and the Sanctuary of Apollo in Hierapolis, a journey through the millennia
}

\author{
Izabela Miszczak
}

January 2019

\begin{abstract}
This paper is devoted to the ancient structure known as the Plutonium that can be seen in Hierapolis, Turkey. It is is an attempt at organising the existing knowledge about the Plutonium of Hierapolis by providing the analysis of the written sources and then putting them in the wider cultural and religious context. The latest archaeological discoveries are discussed and the possible interpretation of their results is provided.
\end{abstract}

Keywords: chthonic deities, ancient religion, archaeology of Asia Minor

\section{Introduction}

In Hierapolis, between a Roman theatre and a nymphaeum, a very peculiar cult centre can be found. It is a complex of structures frequently called the temple of Apollo and the Plutonium i.e. the sanctuary of the Greek god of the underworld. However, the actual function of the cavern labelled as "the Plutonium" is much more complex and far from certain. Recent archaeological discoveries made in the area of Hierapolis helped to answer some of the questions regarding the cult of Hades in this ancient city. They also clarified many of the uncertainties concerning the status of the Plutonium that had been mentioned in the ancient sources and the travelogues of early-modern era discoverers and adventurers. However, many mysteries of this site remain unresolved.

The history of the religious cults of Hierapolis is an excellent illustration of the fact that the religion of ancient Greeks and Romans was not as easy to grasp as some popular myths might suggest. The history of archaeological excavations in this area of Hierapolis is a great proof that archaeology is a thrilling discipline of science and it can surprise us with groundbreaking discoveries, dramatically changing the understanding of even such well-known place as Hierapolis. 
This paper is organised as follows. Firstly, the Greek god called Hades is introduced, and the relation between Hades and Pluto is presented. Next, the idea of necromancy, the cult of Hades, is explained. Further, the known locations of Hades/Pluto cult in ancient times are discussed, with particular attention devoted to Hierapolis. Then, the process of Hellenization of Anatolian deities is presented, especially the case of the Greek god Apollo and its Anatolian connections, as well as the relation between his cult and the cult of Hades. This is followed by the presentation of the Roman building programme in Hierapolis, again focussed on the religious buildings devoted to Apollo and Hades. The ancient sources describing these structures are also presented. We discuss several problems concerning the ancient sources and their discrepancies, including the location of the Plutonium and the timing of its closure. After the discussion of the timing and the causes of the Plutonium's disappearance in the late antiquity, we focus on the travelogues of the European travellers of the early-modern era who searched for the Plutonium. In this section, much attention is paid to discover the similarities and differences between particular travelogues but also between these reports and the ancient texts. Finally, modern research of Plutonium and archaeological excavations are presented, along with some answers to the questions asked in the earlier sections.

\section{Hades, his companions, names, and places of cult}

A Plutonium (or Ploutonion), from ancient Greek $\Pi \lambda \circ \cup \tau \dot{\omega} \nu\llcorner o v$, was a sanctuary devoted to god Pluto, better known as Hades. This Greco-Roman deity was the chthonic god of the underworld, where he dwelled after the universe was divided between him and his two brothers - Zeus and Poseidon. Zeus ruled the skies, Poseidon - the sea, and the solid ground was a domain shared by all three siblings.

Hades had a favourite pet, a three-headed dog Cerberus, and they were frequently portrayed together by classical artists. He also had a wife, Persephone, whom he had abducted from her mother, Demeter. He also employed a ferryman, Charon, who carried the souls of the deceased across the rivers of Styx and Acheron, into the underworld realm of Hades [35].

Despite being the god of the dead, Hades was not perceived as being evil but rather inevitable, as a cold and just god who treated everyone equally. Still, he was a fearsome deity because people were naturally reluctant to meet him.

His name's origins remain uncertain, but Hades is most frequently translated as "the unseen one". This interpretation can be supported by one of his main attributes - the Cap of Invisibility. It had been the gift to Hades from the Uranian Cyclops who offered the lightning bolt to Zeus and the 


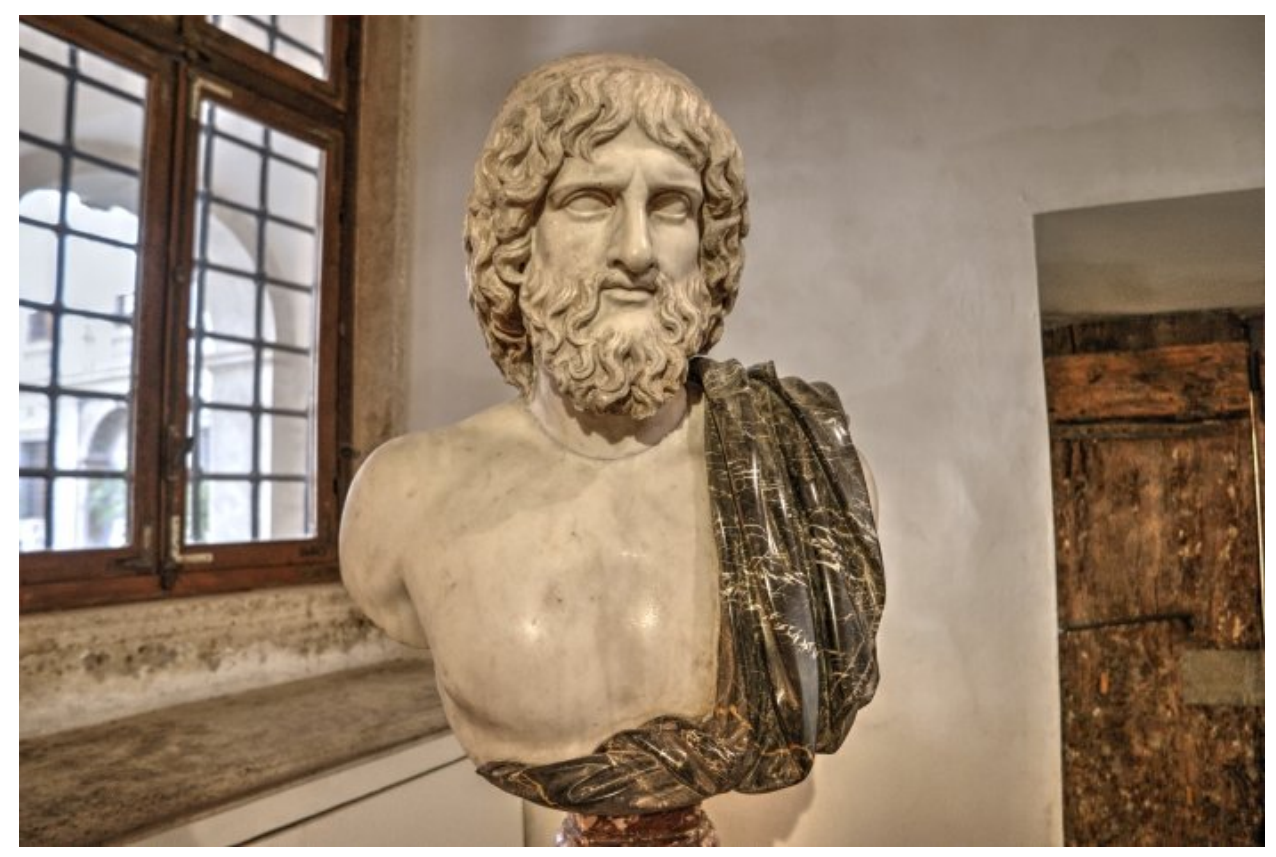

Figure 1: Bust of Hades, Roman copy after a Greek original from the 5th century BCE; the black mantle is a modern addition; now in Palazzo Altemps Museum in Rome, Italy

trident to Poseidon. All these objects were to help the gods in their fight against the Titans.

So strong were the fears of actually seeing Hades that he was called by other names such as Plouton, later Latinised as Pluto. It meant "the giver of wealth" as there were numerous riches hidden underground where Plouton dwelled. This incarnation of the god usually had other attributes, such as the cornucopia - the horn of plenty. In Roman tradition, Pluto merged with Dis Pater, a chthonic god of riches, fertile land, and underground mineral wealth. This connection is clearly visible in the case of Hierapolis where Pluto was worshipped in his own sanctuary as this city was situated near a fertile valley and over rich underground water sources.

Interestingly, Hades was not the first deity to bear the name Pluto. As Diana Burton observed, the epithet Plouton, "the rich one", originated from the Eleusinian Mysteries where Plouton was the deity of the fertile earth, already mentioned in the 5th century BCE [30]. However, the relation of Hades as Pluto and the "Divine Child" Ploutos, the son of Demeter and Iasios, remains unclear. Some scholars, such as Károly Kerényi, even suggest that Ploutos was the son of Hades and Persephone [37.

The process of shifting from the name Hades to Pluto was gradual, and it can be traced back as far as to the 5th century BCE [28]. The earliest 
material evidence of this change is a phiale (a libation bowl) decorated by Douris the painter ca. 490 BCE. Douris was ancient Athenian red-figure vase-painter and potter, very well-known and prolific, with around 300 preserved vases ascribed to him. From this moment, Pluto became recognised as a patron of agricultural wealth within the Eleusinian Mysteries, and the name Hades was rather used to describe the underworld and not its deity. Eleusis in Attica, now Elefsina, was recognised by many ancient authors as the gate to the underworld, but also the place where Hades abducted Persephone. The Plutonium located there consists of two half-caves, but the modern scholars failed to detect any traces of toxic gases.

Not surprisingly, considering the nature of this deity, Hades had very few shrines in the ancient world. However, he was honoured during ancient Greek funeral ceremonies and played a role in the Eleusinian and Orphic mystery cults [37]. As the god of the dead, Hades was a terrifying figure. Thus, people rarely swore oaths in his name. They also averted their faces when sacrificing to him.

As to the nature of these sacrifices, some insights can be gained by the analysis of five lead curse tablets found in Rome. These tablets, dating back to the 1st century BCE, are now in possession of the Johns Hopkins Archaeological Museum in Baltimore. One of them, identified as JHUAM 2011.01, is a curse directed against Plotius, the slave of certain Avonia [34. The curse begins with the invocation to Proserpina (Persephone), Pluto (Hades), and even their three-headed dog. The recipient of the curse is supposed to be consumed by fever and not see another month. The promised offerings are the most fascinating part of the curse: dates, figs, and a black pig for each of Cerberus' heads, and the body of Plotius to Proserpina. John Scheid explains that pigs were characteristic animal sacrifices to chthonic deities [46].

Hades was invoked in the ritual called necromancy (nekromankia), a mystic communion with the ghosts of the dead. Together with his wife, Persephone, he also presided over the oracles of the dead that were called nekromanteia. His only significant cult centre in mainland Greece was the Oracle of the Dead in Thesprotia, in Epirus. Traditionally, this site, on the banks of the Acheron river, was believed to be the door to the realm of the dead. This place was also recognised by the ancients as the location where Odysseus descended into the underworld to meet Teiresias, the seer.

In 1958, the archaeologist Sotirios Dakaris discovered the site called Cichyrus, earlier known as Ephyra. He identified it with the famous Oracle of the Dead, on the basis of its location and similarities to the place described by Herodotus and Homer [31]. These are the remains of a late 4th or early 3rd century BCE complex, sitting on the hill of John the Baptist. Below the central structure, the archaeologist discovered an underground room that he identified as the famous Oracle of the Dead, recounted by Herodotus: Periander had sent messengers to the Oracle of the Dead on the 
river Acheron in Thesprotia to enquire concerning a deposit that a friend had left, but Melissa, in an apparition, said that she would tell him nothing, nor reveal where the deposit lay, for she was cold and naked [2, 5.92G]. However, because of some discrepancies in the descriptions and the problems with dating, the identification of the site remains disputed.

Burton discusses the cult of Hades by analysing information provided by Pausanias, a Greek traveller and geographer of the 2nd century CE [30]:

Pausanias [...] lists several examples of statues or altars in Greece which seem to imply some kind of cult activity, usually in someone else's sanctuary. So, for example, Hades has a statue along with those of Kore and Demeter in a temple on the road near Mycenae; he has an image in the precinct of the Erinyes in Athens; he has an altar under the name of Klymenos [...] in Hermione in the Argolid. And there are a few other places. The one real exception seems to have been in Elis [in the northwestern Peloponnese], where he had a temple and sanctuary; although even here, the temple was opened only once a year because, Pausanias supposes, 'men too go down only once to Hades' - and only the priest was permitted to enter [6, 6.25.2].

Christos Tsagalis adds that Pluto was worshipped with Persephone as a divine couple also at Knidos, Ephesos, Mytilene, and Sparta [50].

Another place of Hades' worship can be found at the southernmost tip of the Mani Peninsula in the Peloponnese that is now known as Cape Tainaron. However, the death oracle (nekromanteio) situated there was not dedicated to Hades, but to his brother - Poseidon. Unfortunately, the Poseidon's Sanctuary and Death Oracle were dismantled, and the Byzantine chapel of Agioi Asomatoi was built in their location, with the use of the ancient stones (see Figure 2). Very close to this church, there is the Cave of Hades, mentioned by Ovid in Book X of Metamorphoses as the gate to the underworld [4].

The places of Pluto's worship - the Plutonia - were relatively scarce, especially in comparison to the most popular gods such as Zeus or Apollo. It does not mean that the Plutonium in Hierapolis was the only one.

The fearful doors to the realm of Hades were commonly associated with caves or fractures in the ground with smelly gases and lakes of steaming waters. Frequently, toxic vapours were emitted in these places. As Pfanz et al. explain in the chapter devoted to the ancient gates to hell in an excellent book "History of Toxicology and Environmental Health: Toxicology in Antiquity": The vapours were called mephitic vapours [from Mefitis, a goddess of the evil geogenic smells] which resembled the deadly Hadean breath (or the breath of the Hellhound Kerberos) [43.

The presence of the gates to the underworld was often detected by herdsmen who observed the changes in the behaviour of the cattle or noted the 


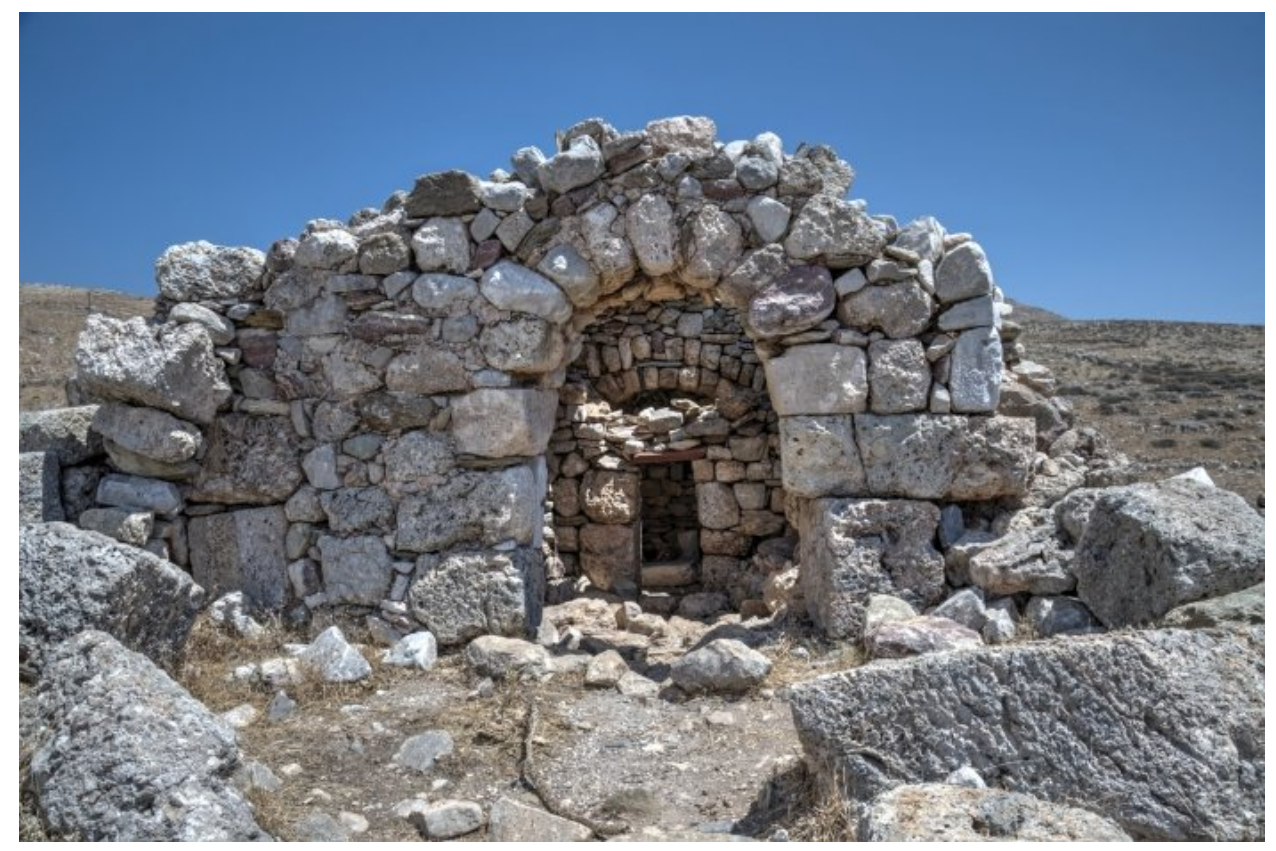

Figure 2: Byzantine church built over the death oracle, Cape Tainaron, Greece

variations in vegetation and corpses of small animals such as birds or rodents. When the priests were notified, sometimes those places were declared, and temples were erected nearby or directly on them, again as it was the case of Hierapolis.

Strabo, the most famous Greek geographer of antiquity who wrote at the turn of the 1st century CE, mentioned two such places, besides Hierapolis, but there were many more, mentioned in Greek and Roman myths.

Strabo used two different words to describe these entrances to the underworld: Charonium - referring to the ferryman Charon, and Plutonium as a sanctuary of Pluto. The first Plutonium was situated in the western part of Asia Minor. In Strabo's own words:

On the road between the Tralleis and Nysa is a village of the Nysaeans, not far from the city, Acharaca, where is the Plutonium, with a costly sacred precinct and a shrine of Pluto and Corê, and also the Charonium, a cave that lies but also the sacred precinct, by nature wonderful; for they say that those who are diseased and give heed to the cures prescribed by the god resort thither and live in the village near the cave among experienced priests, who on their behalf sleep in the cave and through dreams prescribe the cures. These are also the men who invoke the healing power of the gods. And they often bring the sick into 
the cave and leave them there, to remain in quiet, like animals in their lurking-holes, without food for many days. And sometimes the sick give heed also to their own dreams, but still they use those other men, as priests, to initiate them into the mysteries and to counsel them. To all others the place is forbidden and deadly [3, Book XIV, Chapter 1].

According to this description, Acharaca functioned as a healing centre, with a trained cadre of priests. The critical feature of this place was a cave, dangerous for uninvited visitors. As Simon Price mentioned in the chapter "Local mythologies in the Greek East" of "Coinage and Identity in the Roman Provinces": The Plutonium at Hierapolis was in competition with the sanctuary at Nysa 90 kilometres to the west down the Maeander valley, which also laid claim to this myth [i.e. the Abduction of Persephone] [45]. The claim of Nysa to be the place of this event was its name, because according to the "Homeric Hymn to Demeter", it occurred on the Plain of Nysa [1, line 17]. Despite the panhellenic knowledge that such a plain existed in Eleusis, the Nyseans managed to relocate this myth to their home ground.

The remains of this site, now called Akharaka, can still be visited, near Salavatlı village in Aydın Province of Turkey, while the excavated artifacts are on display in the Aydin Archaeological Museum. At the site of Akharaka, there are fragments of an ancient temple, that was peripteral, in the Doric order with 6 by 12 columns. Most probably, it dates back to the Hellenistic period, but it was later reconstructed in the Roman era and then turned into a church. The Princeton Encyclopedia of Classical Sites, published in 1976, mentions that the ancient walls and fortifications were also visible [49. However, modern travellers' reports suggest that only a part of the temple is accessible. It is also challenging to get there, as it is necessary to drive uphill through the village of Salavatl and then walk for half a kilometre.

The second Plutonium discussed by Strabo was situated in Campagna, in the Apennine Peninsula, very close to Cumae. In this case, however, Strabo questions the authenticity of the Plutonium and attributes the belief of its existence to the local tradition. Anyway, if there had been a Plutonium on the volcanic crater of Mount Avernus, in the times of Strabo it ceased to be a place of religious worship of Pluto:

And the natives used to add the further fable that all birds that fly over it fall down into the water, being killed by the vapours that rise from it, as in the case of all the Plutonia. And people used to suppose that this too was a Plutonian place and that the Cimmerians had actually been there. At any rate, only those who had sacrificed beforehand and propitiated the nether deities could sail into Avernus, and priests who held the locality on lease 
it were there to give directions in all such matters; and there is a fountain of potable water at this place, on the sea, but people used to abstain from it because they regarded it as the water of the Styx; and the oracle, too, is situated somewhere near it; and further, the hot springs nearby and Lake Acherusia betokened the River Pyriphlegethon [3, Book V, Chapter 4].

Even after a very brief analysis of the descriptions provided by Strabo, a pattern concerning the location and function of the Plutonia emerges. These shrines were founded at such sites where toxic emissions were present, and the shrines themselves represented the gates to the underworld. Moreover, the presence of poisonous gases seeping from the underworld implies some religious activities organised there, such as healing or prophesying. All these clues lead towards the case of the Plutonium in Hierapolis. Strabo described it in the following words:

When one crosses over the Mesogis, between the Carians and the territory of Nysa, which latter is a country on the far side of the Maeander extending to Cibyratis and Cabalis, one comes to certain cities. First, near the Mesogis, opposite Laodiceia, to Hierapolis, where are the hot springs and the Plutonium, both of which have something marvellous about them; [...] the Plutonium, below a small brow of the mountainous country that lies above it, is an opening of only moderate size, large enough to admit a man, but it reaches a considerable depth, and it is enclosed by a quadrilateral handrail, about half a plethrum in circumference, and this space is full of a vapour so misty and dense that one can scarcely see the ground. Now to those who approach the handrail anywhere round the enclosure the air is harmless, since the outside is free from that vapor in calm weather, for the vapor then stays inside the enclosure, but any animal that passes inside meets instant death. At any rate, bulls that are led into it fall and are dragged out dead; and I threw in sparrows and they immediately breathed their last and fell. But the Galli [priests of Kybele] who are eunuchs, pass inside with such impunity that they even approach the opening, bend over it, and descend into it to a certain depth, though they hold their breath as much as they can (for I could see in their countenances an indication of a kind of suffocating attack, as it were), whether this immunity belongs to all who are maimed in this way or only to those round the temple, or whether it is because of divine providence, as would be likely in the case of divine obsessions, or whether it is, the result of certain physical powers that are antidotes against the vapor [3, Book XIII, Chapter 4]. 
For many centuries this description provided by Strabo was the basis for many other writings published about the Plutonium of Hierapolis. Moreover, these details were frequently put to the test by the travellers who have visited Hierapolis. Over the ages, many people also recreated the act of throwing small animals to test the deadly properties of the places that were shown to them by local guides as the Plutonium, with bigger or smaller success.

The most precise facts provided by Strabo's description of the Plutonium of Hierapolis are its location, shape and size. The site is below a brow of a hill, the opening is small but deep, and the handrail surrounding it is around 15 meters or 50 feet long. However, this relatively short passage from Strabo rises many doubts and questions.

First of all, the location of the Plutonium provided in an unequivocal way as the text is very general and many places situated below a brow of a hill can be found in Hierapolis. Also, Strabo does not even mention the spatial relation between the Plutonium and the Temple of Apollo. The only suggestion of the connection linking these two cult centres is his mention of the priests of Kybele who entered the cavern. As it will be discussed in more details in the next section, the cult of Greek god Apollo was linked to the much older, indigenous cults of Asia Minor, such as the worship of Kybele. Thus, only a very weak connection can be made between the Temple of Apollo and the Plutonium, on the basis of Strabo's text.

Secondly, it is now known that the poisonous gas that killed animals in the Plutonium is carbon dioxide that is deadly in high concentrations. It is heavier than air, thus in the locations where the gas seeps from the underground, for example, due to geothermal activity, it can gather in sheltered places below average ground level. These pockets of highly concentrated carbon dioxide are the cause of suffocation of animals and humans alike. All these facts seem to confirm Strabo's description but for one small detail: carbon dioxide is colorless, but Strabo mentions the vapour so misty and dense that one can scarcely see the ground. This puzzling discrepancy was discussed by William C. Brice who suggested that although the gas that killed animals was undoubtedly carbon dioxide, the terrifying swirling mists observed by Strabo were the result of water vapours, emitted in geothermal fields [29].

William C. Brice also described his visit to the ruins of Hierapolis in 1950 when he saw a place very similar in nature to the one described by Strabo. It was a vertical cavity filled with some gas that extinguished a match and made it impossible to breathe. There were also the bones of a sheep at the bottom that was covered with green slime. Brice concluded that there is no certain identification of the place he visited with Strabo's Plutonium but the same poisonous gas filled it. Therefore another question arises: was there just one place in Hierapolis that could be called a Plutonium? Or were there several deadly caverns known to the ancients, but only one of them was the 
place of Hades' worship?

One mysterious issue seems to be clarified by Strabo himself - how did the priests survive in the poisonous atmosphere of the Pluto's shrine? Despite offering various explanations such as a special immunity possessed only by eunuchs or divine providence, it is apparent that they just held their breath, possibly after undergoing a breathing-control training.

However, this simple solution brings us back to the first problem: what were the priests of Kybele doing in the sanctuary devoted to Hades? A very probable explanation was offered by Frederick Brenk in his book "Relighting the Souls: Studies in Plutarch, in Greek Literature, Religion, and Philosophy, and in the New Testament Background". In one of the chapters, the author analyses the process of Hellenisation of indigenous Anatolian deities and uses the case of Hierapolis as an example [52]. This leads to a whole range of fascinating insights related to the religious cults of ancient Asia Minor.

\section{Hellenization of Anatolian deities and the pecu- liar case of Apollo}

Hierapolis was situated in the border area between the Anatolian regions of Phrygia and Lydia, with their own sets of local gods that were not the part of the classic Olympian pantheon. The process of Hellenisation of Hierapolis was initiated in the 3rd century BCE by the Seleucid dynasty. At this time, the settlement that had developed around the sanctuary of Kybele (also known as Meter), Anatolian mother-goddess, started the transformation into a Greek polis. Her shrine in Hierapolis was situated in the area later transformed into the Apollo Temple. However, Kybele was a purely Anatolian goddess, and her distant origins might have gone back to the Neolithic settlements such as Çatalhöyük. She was also the only known goddess of the Phrygians.

In the period of Hellenization of Hierapolis, the priesthood of Kybele started to be treated as a medical institution rather than purely religious one. It is worth remembering that the priests of Kybele - called Galli were eunuchs. Their castration was the echo of the myth of Attis, Kybele's shepherd-consort of somewhat unclear origins [35]. His story changes with ancient authors, but he always cut off his genitals in the fit of madness.

The process of inclusion of Hierapolis into a much wider panhellenic universe meant that the local myths and gods started to be replaced with the Olympian pantheon. It was achieved by the relocation of panhellenic myths and creating their local versions. In Hierapolis, one such myth was the abduction of Persephone by Hades. While the Nyseans claimed this myth on the basis of the name of their city, the inhabitants of Hierapolis supported their version by the unique nature of their place, with deadly 
gases emitting from the underworld.

In the Hellenistic period, the ruler cult was introduced in Hierapolis, with the members of the Attalid dynasty first transformed into gods after their death, but later equalled to the deities while still alive. Meanwhile, the Delphic god Apollo started to replace Kybele as the chief deity of Hierapolis. In this city, he was worshipped as Archegetes or Pythikos. Archegetes in ancient Greek means a leader or a founder, and on the coins from Hierapolis he is depicted with a lyre, or as the sun god, with a radiate head. This epithet has reference either to Apollo as the leader or the protector of colonies. On the other hand, Pythikos means "from the region of Delphi" and points to the prophetic activities of the god.

It seems that in the Hellenistic times almost all of the religious activities of Hierapolis revolved around Apollo and his closest family. His mother, Leto, was adapted to the local Meter/Kybele cult, while his father, Zeus, was venerated under many epithets, most notably Bosios [24]. As Frederick Brenk suggests, this name was probably related to another local god of Asia Minor, a companion of goddess Eubosia. The chief religious festival of the city was the Letoia, named after the goddess Leto [52]. The statue of Leto can be seen in Hierapolis Archaeological Museum, but it dates back to a much later period, i.e. the 2nd century CE (see Figure 3).

Hierapolis was chiefly a healing centre, so it is only natural that Asclepius held a prominent position there. He was the son of Apollo but had an inferior position to his father. As Ioannis Liritzis explained: Asclepius having half mortal nature does not allow him to be worshipped in the absence or mentorship of his mighty father Apollo [38].

Apollo himself gained another epithet as he became known as Apollo Kareios, incorporating the characteristics of the Anatolian god of oracles, Kareios. This is not surprising, because Apollo, among his numerous activities, was also an oracular god, with his main sanctuary at the Delphic Oracle. There were also other prophetic centres related to Apollo, much closer to Hierapolis, such as Didyma or Claros. In the process of re-identification with Kareios, Apollo reconfirmed his prophetic skills and got the double axe as the characteristic attribute. Inside the museum building in Hierapolis, there is a statue of Apollo Kareios. This statue was discussed by Gül Işın:

[...] a statue bearing an inscription of Apollo Kareios. It was found in the theater in 1975 and is dated to 202-215 A.D. Apollo Kareios is known as the local god of Caria and the worship of Apollo is regarded as the main cult in the city. [...] Since the hands of the statue from the Hierapolis Theater are broken at its elbows, nothing is known about the attributes such as laurel tree or patera that it held. However the manner of its dress, in short chiton and chlamys with semi high boots, presents once more a parallel image to the Apollo Sideton typology [36]. 


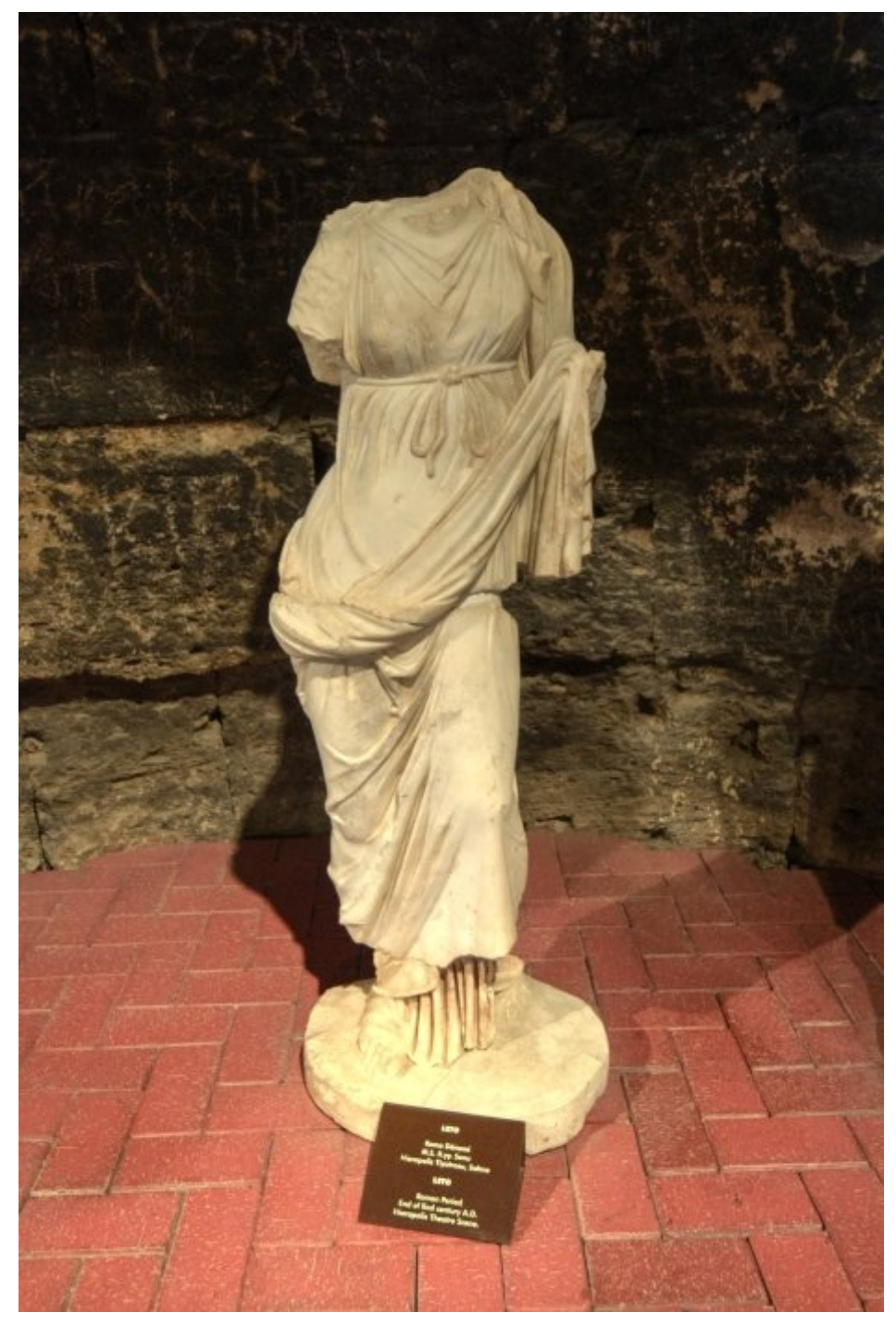

Figure 3: Statue of Leto, Roman period, the end of the 2nd century CE, found in the Roman theatre of Hierapolis, Hierapolis Archaeological Museum, Turkey

Moreover, two inscriptions with the prophecies of Apollo Kareios can be seen in the local museum.

Apollo also absorbed another local god, Lairbenos, who had been initially a sun god, wearing a radiate crown and a special cloak called pallium. Ioannis Liritzis et al. discussed this god in the following words:

Lairbenos is a youthful Anatolian god, often represented on horseback, with a cape and the double-headed axe. This god was subsequently identified with Helios Apollo and considered as a 


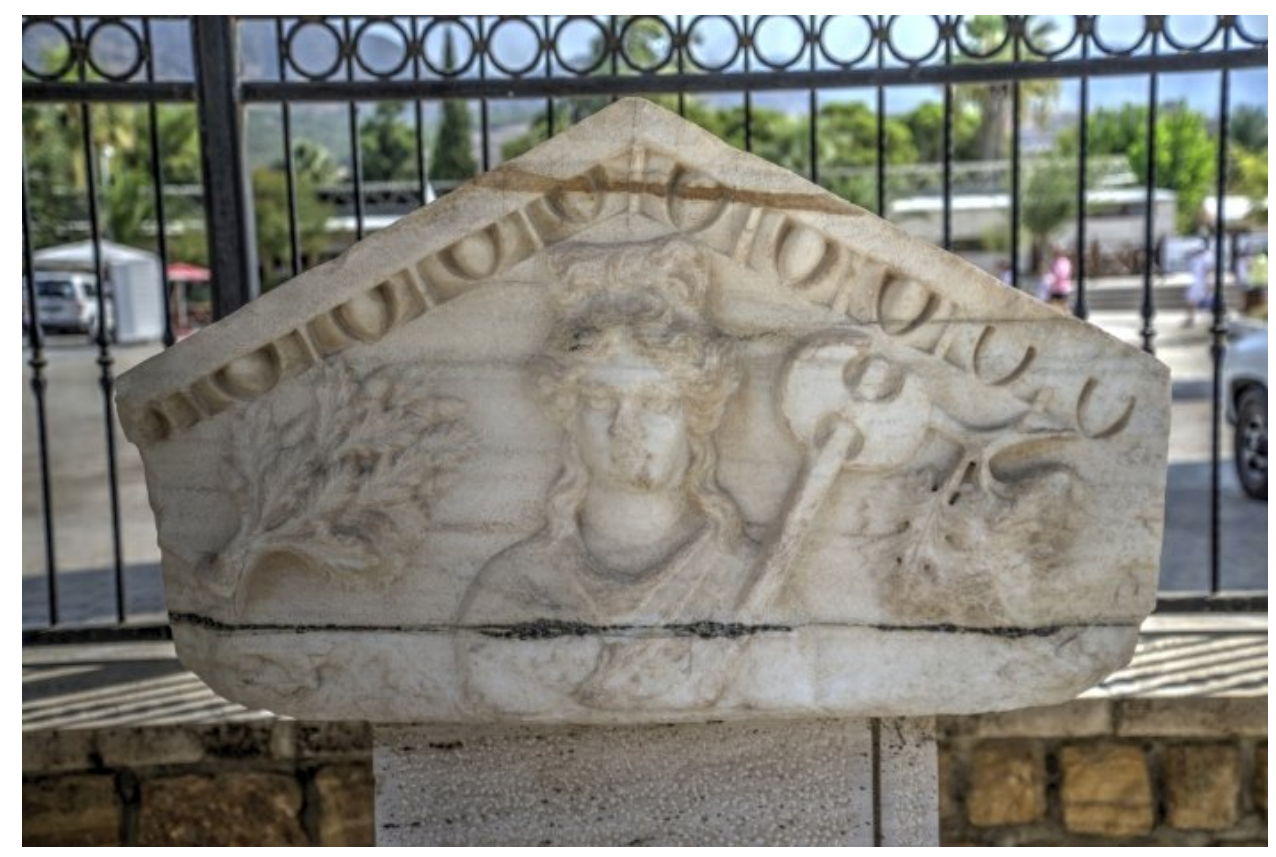

Figure 4: Apollo Lairbenos relief, the 2nd century CE, Hierapolis Archaeological Museum, Turkey

prophet and a physician by the Hellenized populations. [...] The numismatic evidence from Hierapolis shows the double-headed axe of Apollo Lairbenos with Asclepius' snake encircled around it. These coins link Apollon Lairbenos to the healing cult of Asklepios [38].

In the garden of the Archaeological Museum of Hierapolis, there is a relief depicting Apollo Lairbenos with so-called labris, i.e. a double axe (see Figure 4). It was found in the area of the Roman theatre and was dated to the 2nd century CE. The second relief of Apollo, from the same period, shows a more classical face of the god.

In Hierapolis, the sanctuary of Apollo Lairbenos was erected in the vicinity of the ancient cave filled with poisonous gases. Thus, the shrine of Kybele lost its independence, becoming a part of the holy district of Apollo. The only evidence of the late-Hellenistic temple of Apollo are some foundations, but the remains visible today are mainly from the 1st to the 3rd century CE. Some column capitals of this earlier structure are on display in Hierapolis Archaeological Museum.

The cavern filled with poisonous gases, situated next to the temple, was until recently identified with Strabo's Plutonium and it is still labelled as such at the archaeological site of Hierapolis. However,today its role in the ancient times remains uncertain and it is possible that it was used by the 
priests of Apollo and/or Kybele for prophetic or healing functions, and that it was unrelated to the cult of Hades.

Moreover, Kevin Miller suggested that the cult of Apollo Lairbenos might have had its origins not in Hierapolis but in another sanctuary, located some $36 \mathrm{~km}$ to the north-east, on the southern shore of the Meander. Thus, let us take a closer look at the site of this temple dedicated to Apollo Lairbenos [40].

The main Apollo Lairbenos Sanctuary stood on a spur of the plateau that projected above the canyon of the fast-flowing Meander, at the magnificent solitude, separated from all the cities of the area. The distance to Hierapolis, as the crow flies, is around 35 kilometres. On the basis of this significant distance, and the analyses of the inscriptions found in the temple, many authors, including Ramsay and Miller, suggested that the Apollo Lairbenos Sanctuary was not originally under the control of Hierapolis. Ramsay was convinced that the shrine was controlled by the city of Dionysopolis, situated probably 5 kilometres to the south, but the exact location of this site remains uncertain. [40, 25] However, Miller supported the theory that the sanctuary was under the protection of Motella/Pulcherianopolis, modernday Yeşiloba, situated on the other bank of the Meander, some 4 kilometres to the north [40].

Therefore, it is very probable that Hierapolis did not control the region of the Apollo Lairbenos Temple in the Hellenistic period. Furthermore, it could mean that the cult of Apollo Lairbenos was only introduced in Hierapolis in the Roman Period, in the 2nd century BCE or even later. This claim is supported by the coins minted in the city, depicting this deity. Moreover, as Miller suggests, Apollo Lairbenos became the official god of Hierapolis after the city gained control of the territory around his sanctuary.

Recent archaeological excavations conducted in the area of Apollo Lairbenos Sanctuary brought a wealth of materials concerning this cult. The principal reports of these works were published by Esengül Akıncı Öztürk. He explains that, according to a discovered inscription, the temple's portico was built by the slaves of the temple, and dedicated to Apollon. Moreover, according to the pedestals of the statues, the temple of Apollon Lairbenos was a famous and vital religious centre, and its symbol was the double axe [42].

The site of this temple can be visited, near the village Bahadınlar, on a hill which overlooks the Menderes River. The ground floor of the temple is in Hellenistic style, but the other parts are Roman. Some columns are standing on the southern side of the temple, and parts of the portico are still visible on the west side. The temple building measures around 12 to 27 meters, so it is slightly narrower but much longer than the Apollo Temple in Hierapolis. 


\title{
4 Monumental building projects of the Roman Era and the decline of ancient gods
}

Nevertheless, let us return to Hierapolis and its deities. In the 2nd century $\mathrm{BCE}$, Hierapolis was incorporated into the Roman world and was then discussed by the Roman authors. One of them was Pliny the Elder who lived in the 1st century CE. His "Naturalis Historia" (Natural History) later became a model for modern encyclopedias. His main interests were in natural and geographic phenomena, so it is not very surprising that he was also curious about Hierapolis. Unfortunately, he was rather brief when discussing this place:

\begin{abstract}
Also at Amsanctum, in the country of the Hirpini, at the temple of Mephitis, there is a place which kills all those who enter it. And the same takes place at Hierapolis in Asia, where no one can enter with safety, except the priest of the great Mother of the Gods. In other places, there are prophetic caves, where those who are intoxicated with the vapour which rises from them predict future events, as at the most noble of all oracles, Delphi [5, Book 2, Chapter 95].
\end{abstract}

The Romanization of Hierapolis witnessed many ambitious construction projects. Among them, the complete rebuilding of the temple of Apollo is worth noting. The temple stood within a sacred area surrounded by temenos, i.e. an enclosure wall. This monumental phase of Apollo sanctuary dates back to the 1st century $\mathrm{CE}$, but further major restructuring was carried out in the 3rd century CE.

The temple stood next to the main street of the city, and its front was parallel to the street, facing south-west. The temple had a marble staircase, and its back was supported by a hill. The frontal part of the building was erected on the podium, approximately 2 meters high. The other sides southern, western, and northern - were delimited by a marble portico, partly excavated. It had pilasters bearing fluted Doric semi-columns. The reconstruction in the 3rd century CE was carried out by reusing the stone blocks from the older temple. The temple had unusual dimensions as its cella was broader than it was long, and the whole building measured approximately 20 to 15 meters. Today, little has remained from this temple, except its marble stairs and a podium (see Figure 5).

Recently, a comprehensive study of Apollo sanctuaries and their astronomical orientation was conducted by Liritzis et al. They analysed the temple of Apollo Lairbenos on the Meander but did not include the Apollo Temple in Hierapolis into their study [38. This omission was later rectified by another scholar, Amelia Sparavigna, who conducted the analysis of the temple's orientation and concluded that it is possible that it had been ori- 


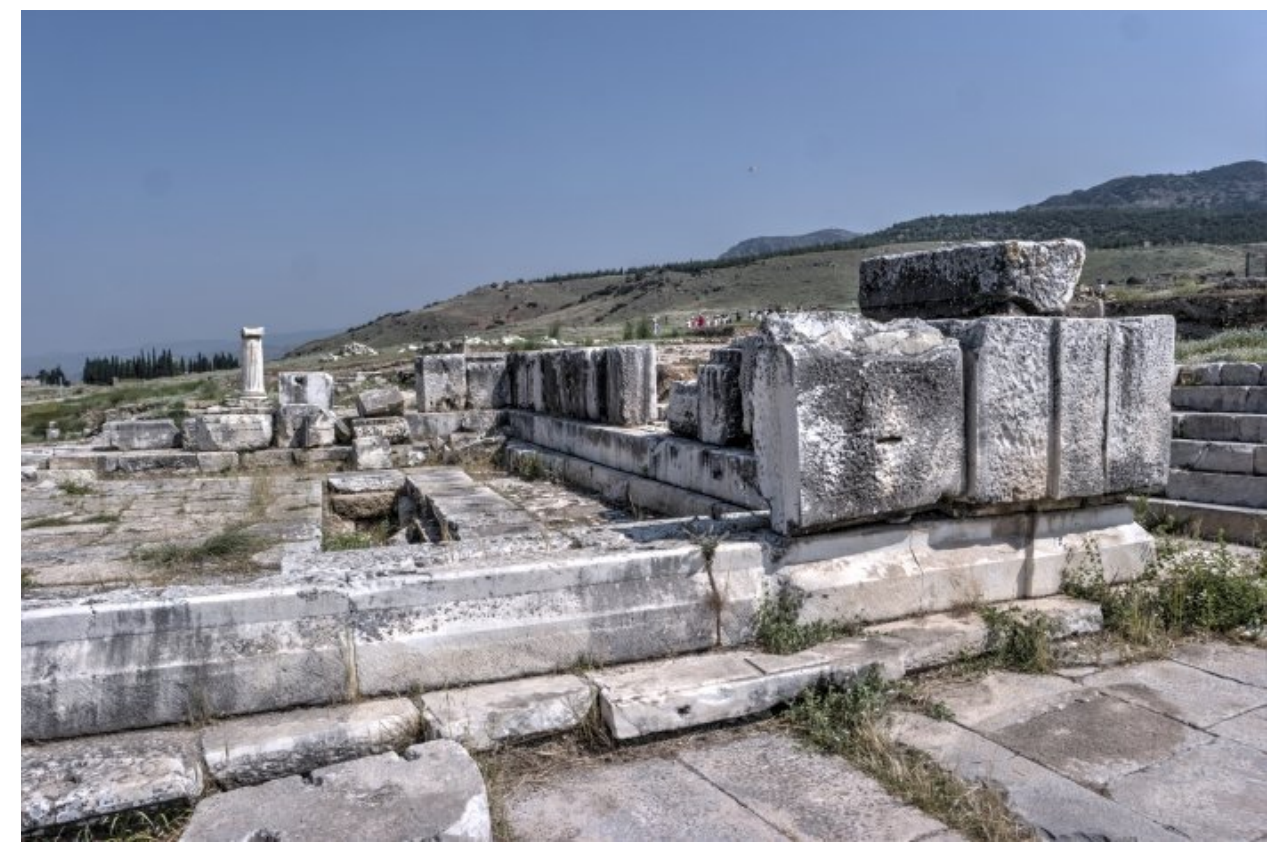

Figure 5: The ruins of Apollo Temple, Hierapolis, Turkey

entated to the sunrise on the summer solstice [47]. This is a very elegant suggestion since the temple had been dedicated to the god of the sun, or even two of them: Anatolian Lairbenos and Greek Apollo.

Strange events occurred in the mid-2nd century CE when a pestilence struck Hierapolis. Despite having a residing oracle, the councillors decided to send a delegation to the oracle of Apollo in Claros, some $170 \mathrm{~km}$ to the west. The reply they got is still visible, carved into the face of the corner block of the temple's cella. The Oracle of Claros suggested ritual offerings to gods, the erection of Clarian Apollo statues, worshipping Apollo Kareios, and sending a delegation of young singers to Claros.

Miller [40] points out some surprising facts concerning this oracle. First of all, no record of Hierapolis delegation was found in Claros, and other such visits from the Imperial period were thoroughly documented. The second surprise is the very little attention that the oracle devoted to the pestilence. Finally, the blocks bearing the inscription with the text of the oracle were reused as a building material in such a way that the text was hidden from the view. Thus, it is probable that the prophecy had not been intended for the Apollo Temple in Hierapolis. The stone blocks bearing the oracle's words may have been just reused as the material to reerect the Apollo Temple after it had collapsed in the earthquake at the turn of the 2nd and the 3rd centuries CE.

Temples dedicated to Apollo were frequently erected over geologically 
active sites, and the one in Hierapolis was no exception. Moreover, the temple of Apollo in Hierapolis sits directly over a fault line, and it had been deliberately erected over it as a direct connection to the chthonic realm. As Stewart and Piccardi convincingly explain, active fault lines were "the fatal attraction" to the many populations as they provided abundant water sources and fertile land [48]. In the eastern Mediterranean region, the seismic fault lines frequently penetrate the hearts of ancient settlements, as is the case at Priene, Ephesus, or Sagalassos.

Because of this deliberate location of the Apollo Temple in Hierapolis, a connection between local Anatolia cults and imported Greco-Roman gods was strengthened: Apollo resided next to the ancient sanctuary of Kybele, and in time, Pluto took over the cave of deadly fumes. As it has already been mentioned by Strabo, priests sold small animals to the visitors, so that they could personally test how dangerous this area was. Convinced of the unusual nature of the place, visitors could, naturally for a fee, ask questions of the Pluto's oracle. This practice supported the Temple of Apollo financially.

Mark Wilson made an interesting comment concerning the parallels between the Plutonium and the Abyss in Revelation. This underground chamber of tortures was called Appolyon, the Destroyer: They have as king over them the angel of the abyss, whose name in Hebrew is Abaddon, and in Greek, Apollyon [Revelation, 9:11]. This analogy represents another connection between Apollo and the underworld and provides a link between the religion of antiquity and Christianity [51].

In the Imperial period, Cassius Dio, a Roman statesman and historian of Greek origin, visited Hierapolis and reported this fact in the following words:

I saw another opening like it at Hierapolis in Asia, and tested it by means of birds; I also bent over it myself and saw the vapour myself. It is enclosed in a sort of cistern, and a theatre had been built over it. It destroys all living things save human beings that have been emasculated. The reason for this I cannot understand; I merely relate what I saw as I saw it and what I heard as I heard it [7, Book LXVIII].

The most interesting element of this description is the mention of a

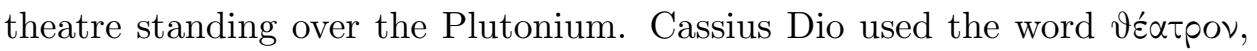
that literally translates as "a place for viewing". It opens new perspectives and possibilities of explaining the details of the cult of Hades. One can now imagine a religious gathering or a throng of spectators, seating on the seats of this theatron and watching some ceremonies, prayers, or sacrifices. On the other hand, this is the first and last ancient source to mention the existence of this structure over the Plutonium and as such it requires a short explanation related to the theatres of Hierapolis. 


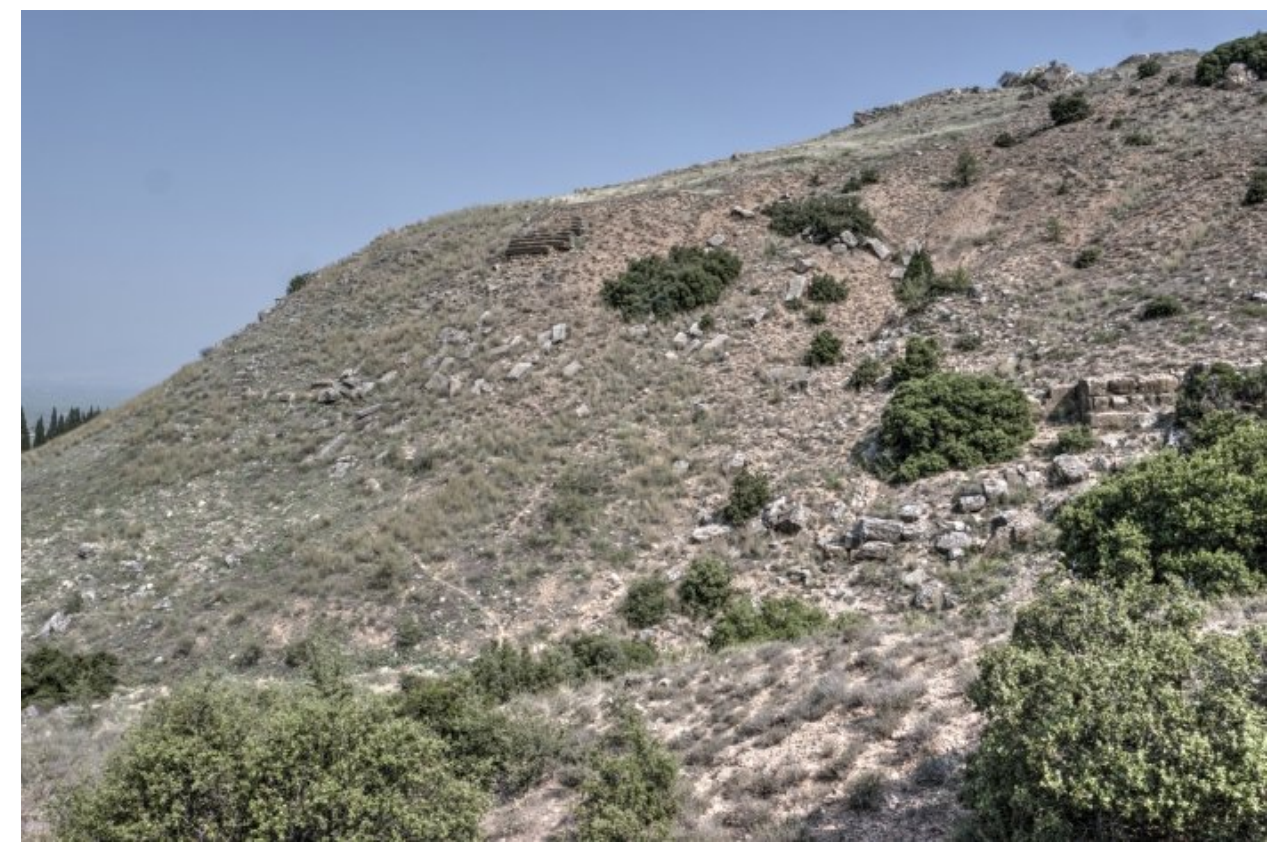

Figure 6: Hellenistic theatre on the northern side of Hierapolis, Turkey

Until recently, only two structures in the area of Hierapolis could be described as a theatre. The first one was situated in the northern part of the site, some 200 meters outside the city walls. This theatre, dating to the Hellenistic period, was erected between two hills, with central section built across valley between them [53. It has never been carefully investigated by archaeologists, and its state of preservation is very poor (see Figure 6). Francesco D'Andria, who has conducted the excavations of Hierapolis for many years, suggested that this theatre was build in the framework of huge development programme of the city, in the same time as the Agora 32 .

The second theatre is the grand Roman building, originally erected in the 1st century $\mathrm{CE}$, but finished in Hadrianic period and rebuilt at the times of Septimius Severus [53]. This impressive structure, still attracting thousands of visitors daily, is situated up the hill from the Apollo Temple (see Figure 8). In the area of this Roman structure, many statues and reliefs were found, showing the cycle of Apollo and Artemis, and consisting of more that one hundred figures [53]. Some of them can now be seen in the local Archaeological Museum. Francesco D'Andria speculated that the fact that Hierapolis could boast of having two theatres was an element of competition with nearby Laodicea that also had two of them [32].

However, none of these two theatres is situated near any structure that can be identified with the Plutonium. Therefore, the short, offhand remark of Cassius Dio was, for a long time, a puzzle to archaeologists and visitors 


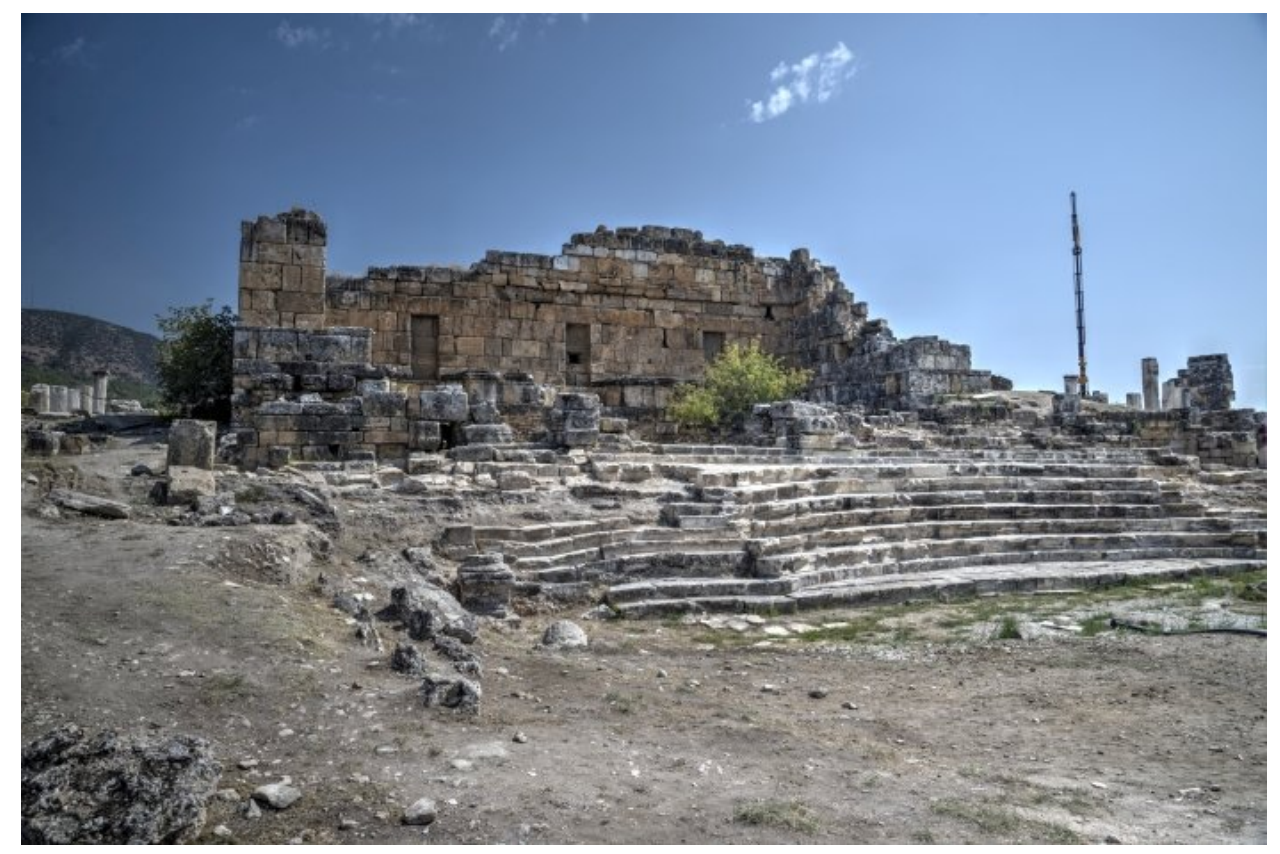

Figure 7: Monumental fountain of the Apollo Temple complex, Hierapolis, Turkey

alike, as it implied the existence of some theatre-like building next to the Plutonium. However, when visiting the place marked as the Plutonium, situated just next to the Apollo Temple, it was clear that no theatre-like structure existed there.

The sacred district of Apollo of Hierapolis also consisted of a monumental fountain, i.e. a nymphaeum, erected in the 2nd or the 3rd century CE (see Figure 7). Originally, this building, constructed of travertine blocks, had a U-shaped ground plan, and now two side walls and a back wall are still standing. The nymphaeum had a vast basin filled with water, and the niches located at the higher level were decorated with the busts of main deities worshipped in Hierapolis. The fountain was fed with the water brought to the city by the aqueducts, and their remains can still be seen between Pamukkale and Karahayit, and near Güzelpınar. Archaeologists excavated the statues of two priestesses, on display in the local museum. The nymphaeum played not only the practical function of water distribution but was also a religious sanctuary itself, as a shrine of the nymphs.

Apart from the gods and goddesses discussed above, there were sanctuaries of Artemis and Poseidon in Hierapolis. Frederick Brenk also mentions the existence of the temples of Heracles and the Twelve Olympian Gods, as well as two temples to the imperial cult. Thus, Hierapolis was not only the centre of the Kybele/Apollo cult, but also, like other significant cities of 
Anatolia, the place of many cults [52].

In the Roman Imperial period, the cult of Kybele, the timeless mothergoddess of Anatolia, virtually disappeared in Hierapolis, hidden among the throng of various deities. The athletic contests held in the 3rd century CE were organised to celebrate the cult of Apollo, who also received a half of all dedications to the gods. The other dedications were made to Artemis, Aphrodite, Nemesis, Tyche, Dionysos, Dea Roma, the Graces, Men, as well as to local gods such as Bosios and Eubosia. By then, Kybele seemed to be forgotten entirely.

The Plutonium in Hierapolis functioned until the 4th century CE, but its later existence remains uncertain. Ammianus Marcellinus, a Roman soldier and historian, who was active at the end of the 4th century CE, mentioned that:

A similar opening was formerly to be seen (as some say) at Hierapolis in Phrygia. And from this also a noxious vapour with a penetrating stench came forth and was destructive to whatever came near it, excepting only eunuchs; and the reason for this may be left to natural philosophers to determine [8, XXIII 6 , $18]$.

He seems to be certain that the Plutonium in Hierapolis had ceased to be active and was no longer to be seen, for an unknown reason. It could have collapsed because of the seismic activity or had been destroyed by the Christians as a pagan shrine. The theory of the Christian action against the Plutonium was suggested by Ramsey who suggested that the Christians [...] had deliberately filled it up and covered over the place, the very dwellingplace of Satan. Ramsay also proposed the possible date of the destruction as to be shortly after the victory of Constantine over Licinius in 324 [25]. This date also fits with the description of Ammianus.

However, the archaeological evidence suggests that sporadic visits to the Plutonium were made for the next two centuries. In the 6th century $\mathrm{CE}$, the entrance to the shrine was walled off, and further earthquakes contributed to its destruction.

When the old gods and goddesses were replaced with Christianity, the ancient religious sites were frequently demolished or desecrated. In the case of the Apollo Temple of Hierapolis, a part of its peribolos was dismantled, to provide space for the enlargement of the fountain. In the 5th century CE, the fountain was strengthened by a retaining wall, built with the spoila obtained from peribolos. By expanding the nymphaeum, the early Christians managed to hide the view of the pagan temple.

It the face of the account of Marcellinus and the onset of Christianity in Asia Minor, the next report from the visit to Hierapolis is somewhat unexpected. At the end of the 5th century, the Neoplatonist philosopher 
Damascius travelled with his teacher Isidoros to the near East and described their journey in "Damascius's Life of Isidoros or Philosophical History". The fragments this book concerning the stay in Hierapolis have been preserved to modern times and their content may sound incredulous:

At Hierapolis in Phrygia stood a sanctuary of Apollo, but under the temple lay the descent to an underground cave, from which fatal vapours rose. Over this gullet, even the lighthearted animals, not even high in the air, can take their way without danger, but all who come into his realm perish. The initiates, however, he says, can even go down to their innermost level and, without harm, stay there. The author says, however, that he himself, and the philosopher Doros, driven by compelling zeal, had gone underground again, and emerged for it unharmed. But the author says: 'I fell asleep in Hierapolis and dreamed that I was Attis and that the Mother of Gods celebrated in my honour the so-called Hilaria Festival.' This dream revealed to me our salvation from Hades [9, own translation from German].

First of all, despite Marcellinus's claims that the shrine of Pluto had ceased to function, it is evident that it was still in use one century later. Moreover, Damascius clearly states that the cavern was located under the Apollo Temple, not at some distance from it. His description does not mention a theatre above the Plutonium, but just an underground grotto. The final surprise is in the text of Damascius who reported that he had dreamt of himself as Attis being entertained by the Mother of Gods who can be identified with Meter/Kybele. Thus, this report makes clear that despite the Hellenization and then the Christianization of Hierapolis, the memory of Kybele and Attis remained there, even in the early Christian era. Damascius's report is the last known work from the ancient times that concerns the Plutonium of Hierapolis.

As William Ramsay convincingly argues in the paper devoted to the cult of Artemis-Leto and Apollo Lairbenos [24, the process of Hellenization in Asia Minor had not been very deep or successful. In his opinion, the Greeks did not manage to depress the popularity of local gods in Phrygia and other regions, except for big cities, the centres of Greco-Roman civilisation. Only after Christianity enforced its beliefs, the Greek language gained the advantage of being the language of the Bible. The last sighting of Kybele in Damascius's dream was thus the swan song of ancient Anatolian cults.

After the account of Damascius, the Plutonium disappeared from the pages of history for many centuries, until its existence and peculiar deadly properties started attracting early-modern era travellers. The ancient city of Hierapolis, damaged by numerous earthquakes, was finally abandoned in the 14th century but it had indeed been only a collection of farmhouses and cottages scattered among the ancient ruins from the 7 th century onwards. 
The ancient texts that mention the Plutonium of Hierapolis that have been preserved to modern time are surprisingly sparse, especially taking into account the extraordinary properties of this sanctuary. For many centuries the description provided by Strabo was the main source of knowledge about the Plutonium and inspired numerous adventurers and scholars alike. Disappointingly, Pliny the Elder was very brief in his treatment of the Plutonium and did not offer any further details in comparison to Strabo.

The most valuable input of Cassius Dio is the information about a theatre above the Pluto's shrine. It is worth remembering that Dio wrote a century and a half after Strabo so the situation in Hierapolis may have changed over such a long period, and possibly the theatre-like building was added after Strabo witnessed the miracles of the Plutonium. Finally, the contradictory remarks concerning the Plutonium and the end of its operation were left by Ammianus Marcellinus and Damascius. Furthermore, all of these ancient sources were known to early-modern era travellers whose search for the Plutonium is discussed in the next section.

\section{Rediscovery of Hierapolis and its Plutonium by the European travellers of the early-modern era}

The existence of the mysterious and dangerous place in Hierapolis, from which deadly gases were emitted, has never been a secret, even in the period when the area was almost completely forgotten. Numerous accounts of early modern era travellers mention that local guides had shown them the place they referred to as "Cin Deliği", i.e. the Devil's Hole. The emerging interest in classical antiquity among European scholars brought the first travellers to Anatolia, starting from the 17th century. In the beginning, their primary interest was in the places described in the Bible, especially the Seven Churches of Revelation, that are all located in the western part of Asia Minor. As one of them - Laodicea - lies just $10 \mathrm{~km}$ to the south of Hierapolis, soon a steady trickle of visitors arrived to gaze upon the white travertine terraces and seek the mysterious Plutonium, described by the ancient authors.

One of these first travellers was Thomas Smith, who was chaplain to Sir Daniel Harvey, ambassador at Constantinople. In the years 1668-1671, he travelled in Asia Minor, collecting information about antiquities but also Greek manuscripts. He spent several years to express his opinions on the affairs of the Levant that were published as a book "Remarks Upon the Manners, Religion and Government of the Turks. Together with A Survey of the Seven Churches of Asia, As they now lye in their Ruines" in 1678. His most relevant observation concerning the cult of Apollo in Hierapolis is the inscription that he saw in the theatre, dedicated to Apollo, translated as To Apollo the chief President. However, he failed to mention the visit to 


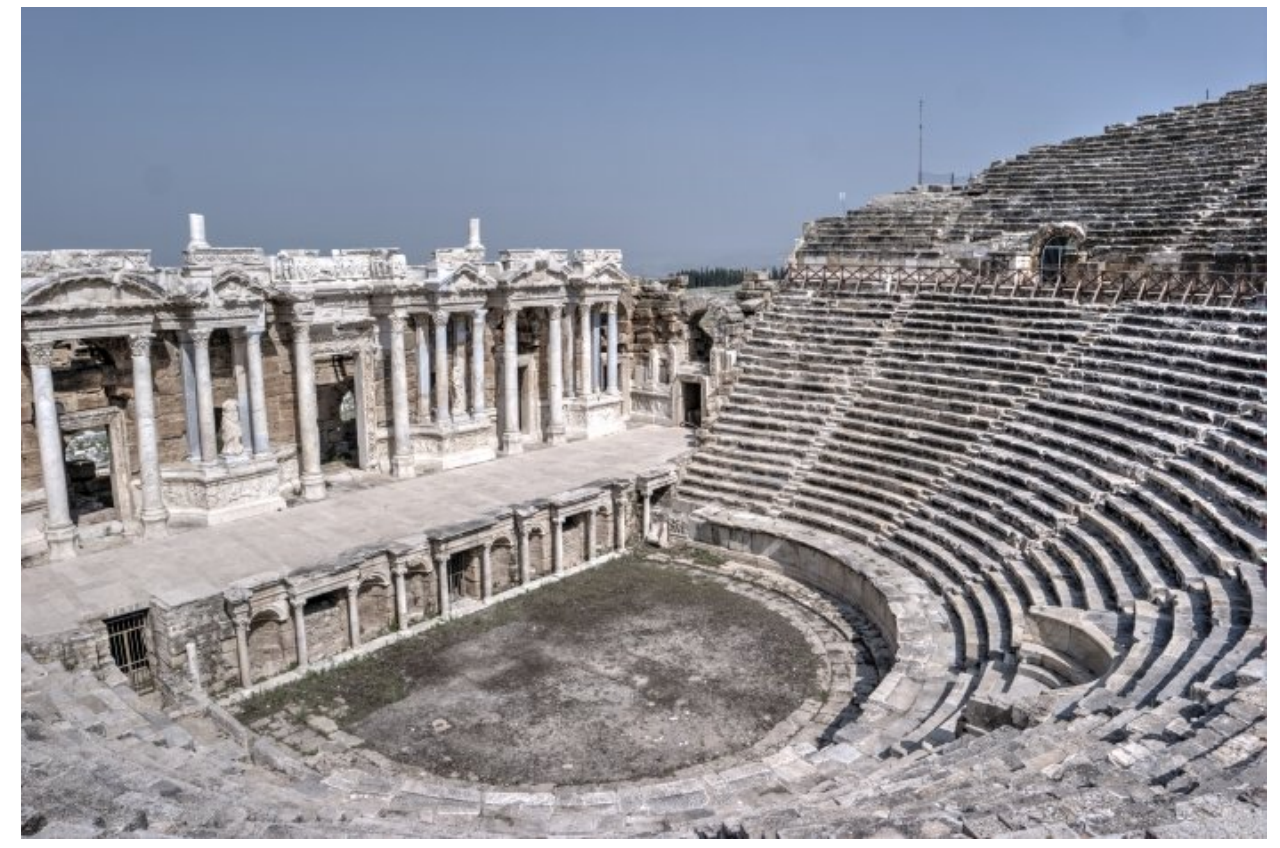

Figure 8: Roman theatre of Hierapolis, Turkey

the Plutonium or any other location with deadly vapours [13].

Soon afterwards, Hierapolis became the destination for two travellers, Jacob Spon and George Wheler, who toured Greece and Asia Minor together in the years 1675 - 1676. One of their goals was to visit the Seven Churches of the Apocalypse, and the visit to Laodicea brought them to the vicinity of Hierapolis. Their journey resulted not in one but two books, telling us about the classical monuments but also about local flora, as George Wheler was an amateur botanist. The first, joint account, "Voyage d'Italie, de Dalmatie, de Grèce et du Levant", was published in 1678, that is in the same year as Smith's book. Here's the relevant fragment concerning the cult of Apollo in Hierapolis: There is still a huge theatre in marble on forty degrees that needs to be considered and in a portal of that theatre is an inscription dedicated to Apollo called Archegetes [11]. This observation is consistent with Smith's independent observation of "To Apollo the chief President" inscription as Archegetes means the leader or the founder [13]. Wheler also published a separate account of the journey, "A Journey Into Greece", in 1682 , but there he mentions Hierapolis only once when describing the location of Laodicea [10].

The next traveller who visited and described the ruins of Hierapolis was Richard Pockoke, an English clergyman and anthropologist, who toured the Near East, including Asia Minor, from 1737 to 1741 . He described his experiences and observations in the "A Description of the East and Some 
other Countries", published in two volumes. In the chapter devoted to Hierapolis of Phrygia, Pococke gave a detailed account of the visible ancient monuments. What's essential, he described some monuments still visible in the sacred district of the Apollo Temple [12]:

[...] there is an oblong square building, which seems to have had an open colonnade to the bason [i.e. the pool]; it is built in a very particular manner, as if it was designed for the reception of statues, and is without doubt the temple of Apollo mentioned by Photius.

Actually, despite the very accurate description of the structure, Pockoke made an erroneous identification as the building he saw was the Apollo Nymphaeum and not the temple.

Even more interesting is his account of the visit to the Plutonium:

They [...] brought me to a deep hole full of water near the bason [the basin he described in the earlier part of the text that can be identified with the ancient pool], which was more strongly impregnated with the mineral, but it had no manner of effect on a bird which I put on the water. They say the water is exceedingly deep, and formerly it was noxious.

Pockoke also described his doubts about the authenticity of the place he had been shown as he confronted it with the description provided by Strabo. The area that Pockoke saw was not situated under the brow of the hill, nor was it in a cave.

Furthermore, Pockoke speculated about the location of the Strabo's Plutonium and proposed a theory that [...] it might be a place to the south-west of the baths, where, below the brow of the hill there is a high wall, which runs from the hill to the south, and then turns to the west. His description fits the present-day path that leads uphill, through the series of artificial travertine pools. Unfortunately, Pockoke failed to test his theory and freely admits that [...] when I was on the spot, as this did not occur to me, so I did not examine into the truth of it.

Around thirty years after Pockoke's visit to Hierapolis, Richard Chandler was sent to Asia Minor by the Society of Dilettanti. He was accompanied by Nicholas Revett, an architect, and William Pars, a painter, and their goal was to explore the antiquities of Ionia and Greece. The journey lasted from 1764 to 1766, and resulted in the publication of the book "Travels in Asia Minor and Greece". The account of their visit to Hierapolis in May 1765 is disappointing because Chandler failed to see the Plutonium and test its deadly properties [14]. His description of the place is just another repetition of the Strabo's account: This was an opening in a small brow of the adjacent 
mountain, capable of admitting a man, and very deep, with a square fence before it.

Chandler admitted that he had tried to locate the Plutonium on the basis of this description but failed. He was offered help from a local person, but his group of travellers was forced to flee for Hierapolis because the local chieftain demanded a share in the treasures they had supposedly plundered.

[...] an old Turk, with a beard as white as snow told me he knew the place, that it was often fatal to their goats; and, accounting for the effect, said it was believed to be the habitation of a demon or evil spirit. We ascended again early in the morning to the theatre, where he had promised to join us; and a live fowl was intended to be the martyr of the experiment. But we met this day with some unexpected interruption which made us leave Hierapolis in haste [...].

Chandler also reported the existence of the inscription to Apollo Archegetes in the theatre, that he copied and translated as the Leader.

Almost half a century passed after Chandler's journey when Hierapolis was visited by William Martin Leake, an English military man, but also a smuggler, responsible for the transportation of the Elgin marbles from Athens to England. In 1799, Leake was sent on a military mission to the Ottoman Empire, to train the Turkish artillerymen as a part of the British campaign against Napoleon. However, the peace treaty signed between the Ottomans and France rendered his mission void. Despite that, he decided to use his time to tour Asia Minor, and his observations were published in 1824 as "Journal of a tour in Asia Minor, with comparative remarks on the ancient and modern geography of that country" [15].

His account of the visit to Hierapolis mentions his predecessors, both ancient such as Strabo, Pliny, Cassius Dio, Ammianus, and Damascius, and contemporary, including Pococke and Chandler. However, Leake had nothing new to add concerning the Plutonium, as he merely repeated the descriptions provided before:

Near the mineral sources which rise in the centre of the site of Hierapolis, Mr. Cockerell observed the Plutonium or mephitic cavern which eluded the search of Pococke and of Chandler. Dio accurately remarks that it was situated below the theatre. Strabo says that it was fatal to oxen placed within its influence and both he and Dio assert that they exposed birds to it, which fell dead immediately.

Several years after Leake's visit, in 1810, Charles Robert Cockerell, an English architect and smuggler, set off on the Grand Tour. Because of the 
Napoleonic Wars, the traditional destinations of the tour, such as Italy, were closed to the British. Thus he headed for Turkey and Greece instead. For some part of the journey, he was accompanied by John Foster, an architect, whom he met in Constantinople. They decided to tour the Seven Churches of Asia and visited many ancient sites on this occasion. However, Foster fell in love, and Cockerell set out by himself. He described his experiences in the travelogue "Travels in southern Europe and the Levant, 1810-1817". Let us check what he learned about the Plutonium of Hierapolis [16]:

I did not forget to inquire for the remarkable cave in which no animal can live, which Chandler tried to find. My guide led me to one near the spring and told me that on certain days birds flying over it fall down, overcome by the fumes. There, sure enough, I did find four small birds with the bones of various other animals. If travellers had been frequent here I could have supposed that someone had put the birds there for sightseers to wonder at; but according to the old aga I am the first traveller here since Chandler's time in 1765 , and it seemed impossible that it should have been done on such short notice merely to make a fool of me. [...] I had bought a live fowl to try Strabo's experiment of putting him into the cave; but whether it was not really the right cave, or whether the violent wind and rain prevented the gas having effect, at any rate the fowl was none the worse after being exposed to it for half an hour, and we ate him with a good appetite in the evening. Over his bones the aga grew talkative, and told me of the real cave which was in the mountain, one hour distant. He said that inside the cave is a bridge, and beyond that a chamber in which is a treasure guarded by a black man. He added that he who should get the better of that black man had need have studied and learnt much. Many and many an adventurer, after the treasure, had died horribly in the cavern. And so on, with all the cock-and-bull stories universal among the Turks.

As it is obvious, Chandler wrote a very typical account, including an attempt to recreate an experiment with an unfortunate bird that was eaten anyway. Yet again, there is obviously much confusion concerning the location of the proper Plutonium as described by Strabo. He was also aware of his predecessor's failed attempts to find the place. Accidentally, the "cockand-bull story" about a cave in the mountains might not be a total fake, as at the end of the 19th century William Ramsay mentioned the existence of "a large rude cave", about six miles north-west of Hierapolis. He suggested that this cave could have been the place of Mother-goddess cult as the name of "the Goddess" could be found among the inscriptions that adorned the 
walls. Thus, such ancient cult centres might have inspired many legends and stories, repeated and distorted with the passage of time.

The subsequent 19th-century visits to Hierapolis and the reports, books, and illustrations that followed display a mixture of the slightly naive approach of the earlier travellers and the nascent scientific curiosity connected with critical views of the ancient sources. An excellent example of such an attitude can be found in a book "Voyage de l'Asie mineure" published in 1838 in Paris. It is a travelogue written by Léon de Laborde, a French archaeologist and traveller, who had embarked on a four-year tour of Italy, Greece, Turkey, Palestine, and Egypt with his father, Alexandre de Laborde. Their travel took them also to Hierapolis, which they reached in 1826. Let us first read the passages related to the Plutonium [17]:

Already the ancients had admired these phenomena, and they recorded in their works the astonishment they had felt. [...] a lair of Pluto, the Plutonium, which exhaled smells to kill a bull on the spot, but which became harmless for eunuchs and especially for priests, it is a question of credulity, and we know how ancient antiquity was gifted of the childish faculty. [...] As for Plutonium, if Strabo, if Dion Cassius had not reported that one says, I would pass them in silence, but they claim to have made the experiment themselves on sparrows, and these birds fell immediately dead on the ground, so we sought this formidable lair, and, for lack of a bird to make the experiment, each of us was disposed to serve [...]. This lair was to be above the spring whose boiling water escaped a little further, after having sunk underground. It has been preserved in the place assigned to him by Strabo. The source springs up from a very small hole, which is sufficient for the abundance of its stream; its waters then fill a reservoir 4 feet long by 6 wide and flow through channels. The inhabitants told us that these exhalations are intermittent, and they added that for 17 years (we are in 1826) they had lost their power. In fact, we plunged a dog, we held it for a long time on the water, I put my face against the spring, and neither my dog nor I felt any untoward effect; much better, we saw camels eat, without being constrained, the algae and fucus that grow on the edge of the water. That was the innocence of these exhalations on the day of our arrival; it was not the same the next day: we found a dead bird near the spring, and our servant was overthrown almost unconscious at the moment when he drew water, the inhabitants do not even have a legend to explain these intermissions, will scientists have a reason? [own translation from French]

Once again, the author of the travelogue relies on the description of 
the Plutonium provided by Strabo in order to find the place. However, at the same time, he is critical when it comes to the immunity of priests and derides the ancient authors as gifted of the childish faculty. The essential element of this report is the fact that Laborde saw the Plutonium (or the place he assumed to be the Plutonium) with his own eyes, unlike unfortunate Chandler some sixty years earlier. Laborde's description offers us its location - above the reservoir of boiling water, and the dimensions of a reservoir. Apparently, the urge to test the toxic properties of the emitted gases was too strong to resist, and the author was even willing to sacrifice his own dog, but no effect was noted. However, the capricious nature of the emissions was evident as the spring emitted deadly vapours the next day, despite the claims of the locals that it had been dormant for 17 years. Finally, it is the first time when someone suggested that this phenomenon could be explained scientifically.

In the same year, 1826, Hierapolis was visited by a group of travellers that included Francis Vyvyan Jago Arundell, an English clergyman and antiquarian from a distinguished family. Four years before, he had been appointed the chaplain to the British Factory at Smyrna, and he had begun travelling around Asia Minor. From March to September of 1826, Arundell and a group of companions arranged a pilgrimage to the Seven Churches of Asia, and his account of the journey was published in 1834, as "Discoveries in Asia Minor, Including a Description of the Ruins of Several Ancient Cities, Especially Antioch of Pisidia". Disappointingly, Arundell had very little to say about Hierapolis, as he fell ill during the tour, and he only mentions the Plutonium which he calls the mephitic cavern [18]:

By my indisposition, all out plans were deranged, and instead of going to Hierapolis, which I was very anxious to revisit, in order to examine with more attention the gymnasium, the mephitic cavern, and, above all, the three large churches, I was obliged to remain in bed $[\ldots]$.

The explanation of the deadly properties of the Plutonium was provided sooner then Léon de Laborde might have hoped. In 1833, Charles Texier, a French historian, architect and archaeologist, arrived in Asia Minor on an exploratory mission, and soon afterwards, in 1839, he published the threevolume "Description de l'Asie Mineure faite par ordre du Gouvernement français". In this book, he devoted a whole chapter to the description of Hierapolis, and the case of the Plutonium was one of the main subjects discussed there. Like all he predecessors, he widely quoted Strabon and Ammianus Marcellinus and noticed the peculiar notion that the Plutonium was located under a theatre, as mentioned by Cassius Dio.

However, the novelty of his approach resulted from the scientific progress in the realm of chemistry, made by his compatriot, Antoine Lavoisier, in 
the second half of the 18th century. Lavoisier, widely considered as the father of modern chemistry, devoted much of his research to carbon dioxide - that he called carbonic acid gas. One of his observations concerned the particular property of this gas as he concluded that any series of lectures in an auditorium extending over three hours would leave the audience in a soporific state due to the accumulation of carbon dioxide. Thus, with the surprising ease, Texier explained the mysterious deadly vapours of the Plutonium [19]:

[...] it is quite simple that the carbonic acid gas which is exhaled in quantity from these waters, since it is heavier than air, has been contained between the borders of this well; hence the asphyxiating virtue of the enclosed air between these walls; there is no need to cite all the places in Europe where this same phenomenon manifests itself, and it does not excite any surprise [...] Thus, Strabo's description makes it clear that the demolition of the balustrade would have given rise to carbonic acid, and would have destroyed the phenomena. [own translation from French]

He also dismissed the magic performed by the ancient priests who survived in the dangerous atmosphere:

As for the faculty possessed by the Galli to plunge their head into this pestilential atmosphere without feeling any effect, it is one of those juggleries so common among the Asiatic priests, that there is no need to seek the explanation. [own translation from French]

Therefore, in the first half of the 19th century, one of the mysteries of the Plutonium - its deadly vapours - was explained and properly described. However, other issues still remained, including the mysterious theatre mentioned by Cassius Dio, the exact location of the Pluto's shrine, and its capriciousness. Texier himself admitted that his observations concerning the Plutonium were purely theoretical as he had failed to locate the place and witness its activity: I confess that myself, knowing all that was written about it, I sought it in vain. Perhaps since Cockerell's trip this well has been filled by the peasants.

In 1838, Charles Fellows, a British archaeologist and explorer, visited Asia Minor, discovering numerous ancient cities, especially in the region of Lycia. His account of the travel - "A Journal written during an Excursion in Asia Minor" - was profoundly influential on the future generations of archaeologists and travellers. It is worth remembering that the idea of archaeological excavations in the 19th century was very different from the modern approach. Fellows himself led the archaeological excavations of Lycian cities and discovered an enormous amount of antique monuments that 
he immediately shipped to England. However, the chapter devoted to Hierapolis is disappointingly brief and fails to mention the existence of the Plutonium and the Temple of Apollo [20].

Anyway, from this moment, the interest in Hierapolis and its Plutonium shifted from mere curiosity to a more professional approach, as the place became a frequent destination not only for travellers and adventure seekers, but also by scholars, historians, and archaeologists.

As travelling throughout Anatolia was made easier with the development of railroad and road network in the second half of the 19th century, modernera tourism also started to be possible. What was a trickle of travellers in the 19th century, in time became a flood of tourists that nowadays visit Hierapolis daily by the thousands. However, not many of these tourists are aware of the existence of the Plutonium among the ruins as most of them are lured by the white terraces of Pamukkale and the sparkling waters of the Ancient Pool. No doubt, if adequately informed about the ancient traditions related to the Plutonium, at least some of them would be tempted to test the deadly properties of this place, in the manner already described by Strabo.

The typical early-modern example of this touristic approach was provided by Edwin John Davis, who published "Anatolica: Or, The Journal of a Visit to Some of the Ancient Ruined Cities of Caria, Phrygia, Lycia, and Pisidia" in 1874. In the preface of this book, Davis admits that visiting Asia Minor had been his dream since his childhood when he had read Charles Fellows' account. Davis' own travelogue provides an extensive description of Hierapolis, including the travertine terraces, the necropolis, the octogonal church, the theatre, and the city gates. Davis copied numerous inscriptions of the ancient city, prepared a plan of the part of the city, and included many drawings and even photographs in his book. By the time of his visit, the existence of carbon dioxide deposits in Hierapolis was common knowledge as Davis casually comments: The hot water of the source is strongly charged with carbonic acid gas. He develops the subject of the deadly gases of Hierapolis in the following words [21]:

From every hollow in the ground along the bottom of the hill, from every little patch of marsh, carbonic acid gas issues with a hissing sound; bubbles of the gas rise incessantly from the bottom of the great source and mount upwards to the surface, like flickering particles of silver. The villagers told us that several persons had been drowned while bathing here, overpowered by the noxious gases, but, as they thought, dragged down by an "efreet" who lived in the spring. Goats, too, were sometimes killed, and one of our party found two sparrows just dead; they had alighted to drink and were stifled by the vapour. Doubtless the exhalations from the waters and earth are sometimes very concentrated and deadly. 
Importantly, Davis observed that the carbon dioxide emissions in high concentrations were emitted not in just one place but from numerous fissures in the ground. This comment is followed by the recount of ancient sources concerning the Plutonium, and the well-known names of Strabo, Pliny, and Cassius Dio appear there. Sadly, Davis adds that Probably this aperture has long been blocked up. We saw nothing resembling it. However, his travelogue includes the first photograph of the "supposed site of the Plutonium", situated next to the Apollo Temple, so the location of the possible Plutonium near the temple had been widely known by then.

Thus, by the end of the 19th century, many travellers had visited Hierapolis and sought its famous Plutonium. Moreover, the existence of the Plutonium in Hierapolis had never been a secret as the early-modern era travellers and explorers were well-read in ancient sources and knew the accounts of Strabo and Ammianus Marcellinus. The problematic part was the determination of the exact location of the Plutonium, and these travellers used local guides to help them identify the exact spot, with mixed results. They were also aware that in this region of Asia Minor, the deadly gases were emitted from the earth not in just one spot but in numerous places, making the precise identification next to impossible. Also, the deadly nature of carbon dioxide had already been explained before any systematic archaeological study of Hierapolis began.

\section{Archaeological research and the solution of some mysteries}

Soon after the Davis' visit, Hierapolis was properly studied and partly excavated. It was visited numerous times by William Mitchell Ramsay, a Scottish archaeologist who later became the foremost authority on the history of Asia Minor. In his book, "The Cities and Bishoprics of Phrygia", published in two volumes, he mentioned that his last visit was in 1887, a few months before the excavations of the site started [25].

In the chapter of the book devoted to Hierapolis, Ramsay widely discussed the Plutonium, traditionally starting from the account of Strabo. He adds that there are other places in Phrygia where the mephitic vapour from the holes in the earth drew down birds flying over them. This is a fundamental observation in the light of the discoveries that were made long after Ramsay's visits to Hierapolis.

Ramsay also assumes that the Plutonium had disappeared in the 4th century, on the basis of Ammianus Marcellinus account. Moreover, he offered a hypothesis that this disappearance can be attributed to the deliberate action of the Christians who filled up and covered over the place, the very dwelling-place of Satan. However, this observation is just a suggestion as the Plutonium may have been damaged or destroyed by one of the earthquakes 
that so frequently occur in the Hierapolis area.

Ramsay also offers inspiring remarks concerning the eunuch-priests who had descended into the Plutonium without harm. Surprisingly, he did not focus on the tricks they must have used such as keeping their breath, keeping the heads high, or staying in the pockets of clean air. Instead, Ramsay discussed the divine nature of these priests who could walk unharmed in the "world of death". He also explained that the annihilation of their sexuality brought them closer to the divine.

Another religious aspect of ancient Hierapolis discussed by Ramsay is the cult of Apollo Lairbenos, so closely related to the Plutonium. He described the institution of Semeiaphoroi, a group of people that he compares to the brotherhood. In Hierapolis, they were united in the worship of Apollo, and one of their primary duties was the hospitality towards the travellers. Next, Ramsay made a very long and highly speculative connection between this ancient brotherhood and the similar societies that existed in Anatolia much later, in the times of the Seljuk Empire. However, this aspect is well beyond the scope of our current discussion.

More to the point, Ramsay offered some insights concerning the functioning of the Anatolian village-system that can be used to understand the functioning of the sanctuary of Apollo. In his opinion, this system was "almost a pure theocracy". The god, in this case - Apollo, was the ultimate guide for the population of peasants dwelling in the villages surrounding the central sanctuary, the hieron. The will of the god was revealed through his priests, and their position was hereditary within a family or several families.

The archaeological research of Hierapolis was initiated in June and July of 1887 by the German archaeologist Carl Humann, best known as the discoverer of the Pergamon Altar. His account of the examination and initial excavation of Hierapolis was published in the report in 1898 as "Altertümer von Hierapolis". Unfortunately, when it comes to the Plutonium, Humann had nothing new to add, as he only recalled the earlier sources and added that The cave, the former Plutonium, had collapsed or closed; where the source lies is unknown today [23, own translation from German].

Surprisingly, after Humann's publication, very little research was done in Hierapolis for the next sixty years. The regular excavations of Hierapolis started only in 1957, under the direction of Italian archaeologists, and they have been continued until the present times. Soon after the initial surveys, in the round of excavations of 1962 - 1965, the opening leading underground was found within the temenos of the Apollo Temple, that was examined at the same time. It was quickly identified as the legendary Plutonium, so sought after by earlier visitors (see Figure 9).

The site consists of a natural chasm in the limestone floor, situated along a travertine wall, just to the south-east of the temple. This opening leads to a grotto filled with hot water and "noxious exhalation", as it was described by Daria de Bernardi Ferrero [33. The identification of this cave 


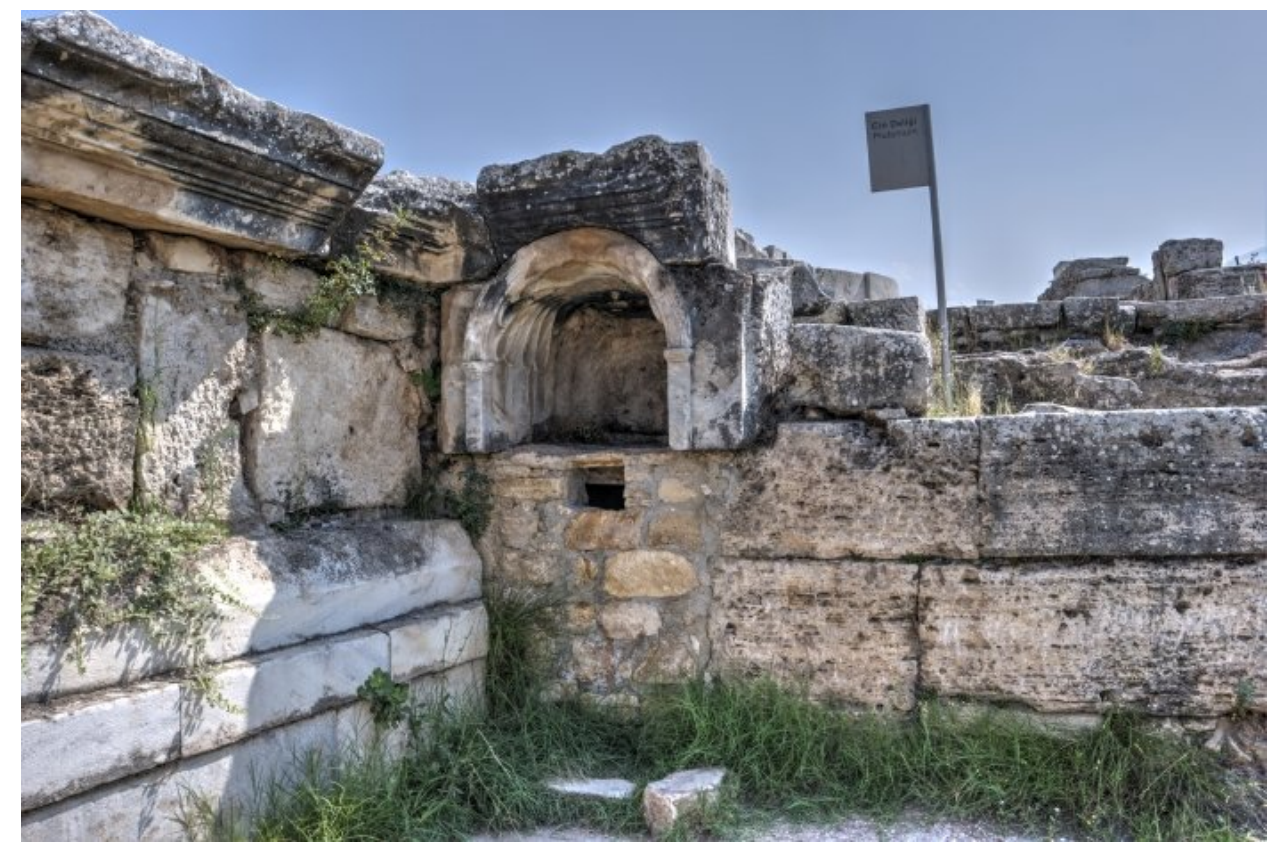

Figure 9: The Plutonium identified in the 60-ties of the 20th century, Hierapolis, Turkey

as the Plutonium was based on several factors: very high concentrations of carbon dioxide inside, its proximity to the temple, and some inscriptions that confirmed that it had been a seat of oracular activity.

However, some unresolved and puzzling issues remained, including the lack of any theatre above the cave, such as the one mentioned by Cassius Dio. Moreover, no inscription had been identified at the site that would link it directly to Pluto. Nevertheless, in 1970, the sign was erected, labelling the location of the Plutonium, next to the Temple of Apollo. For safety reasons, the entrance to the grotto was walled up, to prevent unaware or curious tourists from stumbling inside.

In the early 21st century, the attention of the researchers was drawn to the geophysical properties of the area surrounding the Apollo Temple. Even though the deadly gas that killed small animals at the entrance to the underground grotto had been identified as highly concentrated carbon dioxide more than one and a half century ago, not many systematic studies were conducted from that time. This situation changed with a steady stream of publications devoted to the geology of Hierapolis that have been published recently.

In 2006, Sergio Negri and Giovanni Leucci published a paper that presented a geophysical survey conducted in order to explore the cavities and structures located under the Apollo Temple [41]. The main goal was to de- 
termine whether the cave known then as the Plutonium could be reached by the priests from inside the temple. The paper also provided an accurate description of the temple and the grotto:

"[...] a chamber wide enough for a person to enter and very deep, broadening as one descends. There is a hole $9 \mathrm{~m}$ in diameter surrounded by a fence, which is covered by a thick mist, making it impossible to see inside. [...] any living creature that enters the whole dies instantly."

The researchers also suggested that the results obtained by the application of ground-penetrating radar and electrical resistivity tomography supported the hypothesis that there is a man-made structure below the temple, and it can possibly be the entrance to the Plutonium.

The breakthrough in our knowledge concerning the Plutonium was made soon afterwards. In 2009, the team of archaeologists led by Francesco D'Andria from the University of Salento reported the discovery of the ritual theatre of the Julio-Claudian age, with three rows of seats. Sitting on the natural rock bank, the building has a rectilinear course and is orientated to the fracture of the seismic fault beneath. It was initially described as a building with marble seats intended to accommodate spectators and connected to the ritual events held in the sanctuary. The archaeologists refer to this building as the theatron from the Greek word theaomai that means I observe and was used to describe the audience part of the ancient Greek theatre. This structure was damaged by the travertine channels, formed after the abandonment of the city, in the 7th century CE.

The excavations of the theatron area continued in 2010, including the removal of the travertine channels with the pneumatic hammer. The northern part of the structure and the adjacent stairway were brought to light. As the travertine formations in front of the theatron were also removed, the remains of a marble pavement were revealed. Moreover, an opening in the rock became visible, and the researchers began to speculate about the presence of a cavity below the theatron. Also, the presence of marble fragments suggested that the opening was originally fenced off. In that year's reports, published on the official website of the archaeological mission to Hierapolis, the idea that the discovered structure may be Strabo's Plutonium was expressed for the first time. However, further examination was necessary, and the drainage of the area was required.

Further details concerning the theatron were revealed in 2011 when the monumental façade below the steps and above the spring became fully visible (see Figure 10). The source of water flowing into the structure was decorated by the arch and framed by semi-columns. The greatest revelation of the year was the discovery of the dedication in Greek to Pluto and Kore - "Ploutoni kai Kore" - in the area of the theatron. Little doubt remained concerning the identification of the structure [32]. 


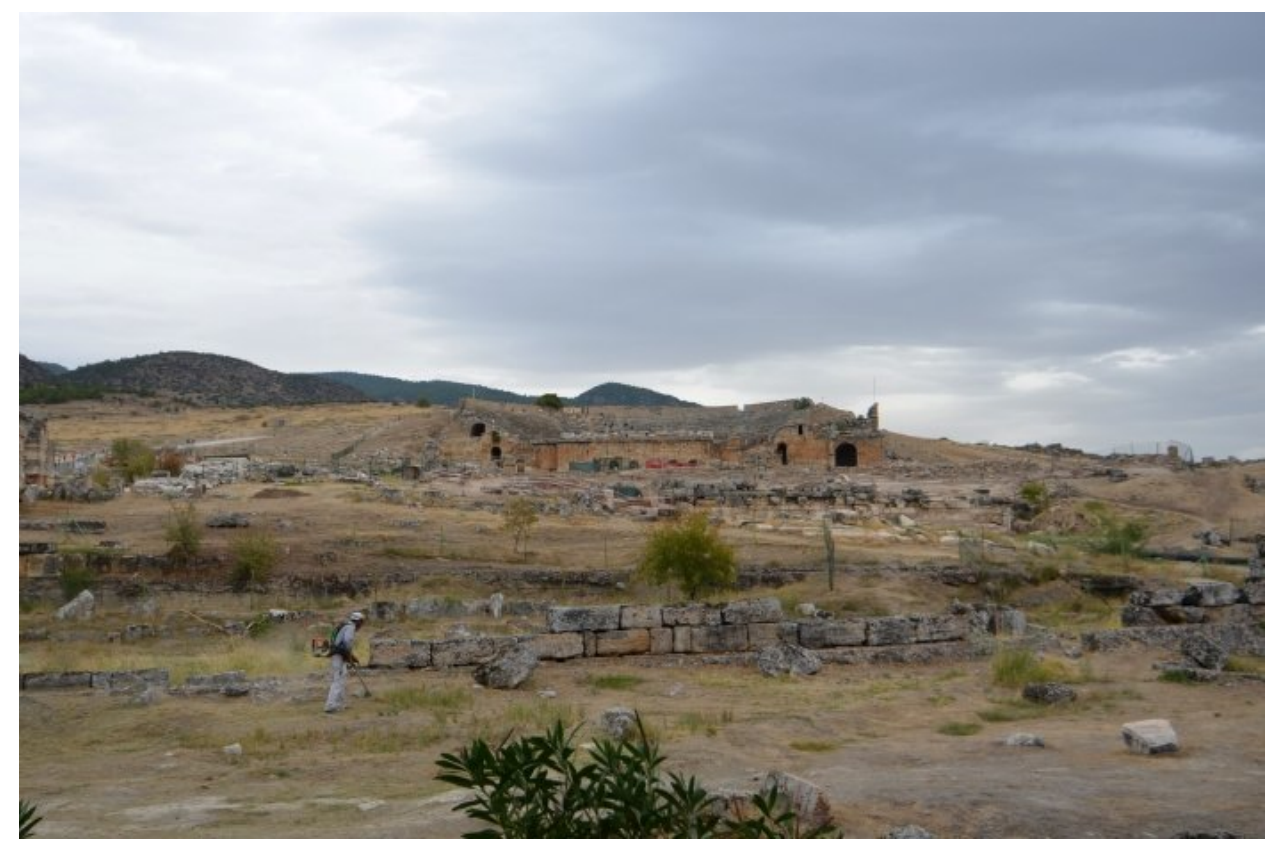

Figure 10: New Plutonium in the foreground and the Roman theatre in the background, 2013, Hierapolis, Turkey

However, the official announcement of the discovery of "the real" Plutonium was made a year later, in 2012. We found the Plutonium by reconstructing the route of a thermal spring. Indeed, Pamukkale' springs, which produce the famous white travertine terraces originate from this cave, proud D'Andria said to the journalists [39]. D'Andria also claimed that all the architectural elements of the theatron matched the descriptions of the Plutonium in ancient sources. The excavations in the area even revealed a significant amount of bones of birds, confirming the accuracy of the Strabo's description. The headlines of Turkish and international journals and news portals were full of exclamations and praise for the Italian archaeologists. In the meantime, many travellers who had visited Hierapolis before this discovery scratched their heads wondering what they had actually seen labelled as "Plutonium" next to the Apollo Temple if the real Plutonium was just recently discovered.

As the mystery of the Plutonium was announced to be solved, numerous new questions and issues arose, including the geological setting of the site, its role in ancient cults, and the function of the "old" Plutonium next to the Apollo Temple. From this moment, the steady flow of the publications devoted to the new Plutonium and the Apollo Temple turned into an avalanche. In 2014, the new Plutonium was described in the book devoted to the history of toxicology as an example of the ancient gate to hell. The authors, including D'Andria himself, described the location of the tem- 
ple and the newly discovered Plutonium that were erected directly above the Pamukkale geological fault. The inside of the Plutonium was described as a subterranean chamber, totally dark but very humid, with a warm, carbonate-rich stream flowing below. The measurements of carbon dioxide concentrations were revealed to be up to $91 \%$. The authors also briefly mentioned the "old" Plutonium, under the Apollo Temple, also standing directly above the same fracture zone. The concentrations of carbon dioxide in this grotto reached up to $65 \%$ [43].

The same book offered the precise geologic background and the thorough discussion of the physicochemical properties of carbon dioxide. The most important facts concerning the toxical properties of this gas are as follows: carbon dioxide is colourless, tasteless, and odourless in the gaseous form. It means that one can walk right into an area of carbon dioxide high concentration without noticing the danger, especially if the gas cloud is gradually increasing its concentration. Carbon dioxide is not classified as a toxic or harmful gas, and its content in fresh air varies between $0.036 \%$ and $0.041 \%$. However, with much higher concentrations of $7 \%$ to $10 \%$, it may cause suffocation, even in the presence of sufficient oxygen. Its influence of living organisms manifests itself as dizziness, headaches, visual and hearing dysfunctions, and unconsciousness within a few minutes to an hour.

The emissions of $\mathrm{CO}_{2}$ in Hierapolis have been known for a long time, but their systematic measurements were only performed in 2014, and the results were made public four years later. In 2018, a paper was published by Pfanz, H., Yüce, G., Gulbay, A.H. "Deadly $\mathrm{CO}_{2}$ gases in the Plutonium of Hierapolis (Denizli, Turkey)". They measured carbon dioxide concentrations in the Temple of Apollo, the old and new Plutonia, and additional fractures and sinkholes nearby by using the portable gas analyser system. The authors also explained that carbon dioxide lakes are only stable when no wind or sun action occurs and thus these concentrations are the highest and the most constant inside the caves, such as two Plutonia of Hierapoli [44].

The question of two underground grottoes in Hierapolis, for conventional reasons frequently called the "Old Plutonium" near the Apollo Temple, and the "New Plutonium", some 200 meters to the east, was briefly discussed by Stewart and Piccardi. They mention that the interior of the "Old Plutonium" is filled with votive offerings to a female deity, related to the natural world, most possibly first known as Kybele, and then as Persephone [48. That means that in Hierapolis there were two separate constructions devoted to the chthonic deities, purposefully placed over the same active fault trace. 


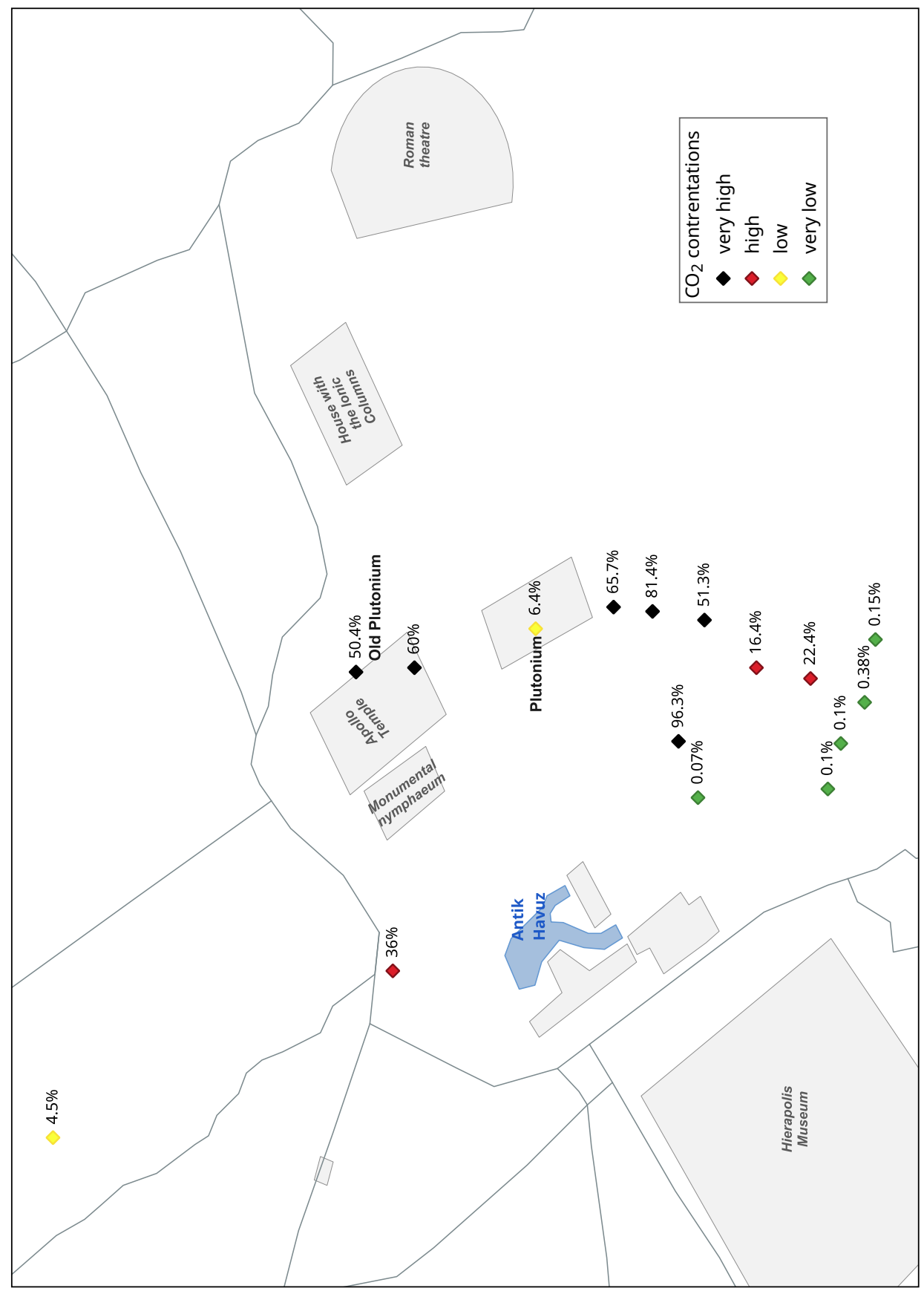

Figure 11: The plan shows the fractures and sinkholes of Hierapolis, classified according to their $\mathrm{CO}_{2}$ concentrations. Green points represent the concentrations below $1 \%$; yellow points - the concentrations from $1 \%$ to $9.99 \%$; red points - the concentrations from $10 \%$ to $49.9 \%$; black points - the concentrations of $50 \%$ and higher. The fault line can be clearly seen, following the points with the concentrations higher than 9.99\%. Data from [44]. 


\section{Unsolved mysteries}

Despite recent revolutionary archaeological discoveries, many questions concerning the religious cults in Hierapolis still remain unanswered, and the case of Plutonium is far from solved. Was the "Old Plutonium" a cave devoted to female deities only or was that also a prophetic centre related to the cult of Apollo whose temple stood above it? This would seem to be a natural solution, with the "Old Plutonium" as the oracular shrine, related to the prophetic nature of earthly vapours. The "New Plutonium" may have been devoted to the second, poisonous aspect of the gases, and as such functioned as the cult centre of the lord of the underworld, Hades.

Moreover, the discovery of the "New Plutonium" at the beginning of the 21 century does not mean that there are no more similar places to be found in the area of Hierapolis. As the study of carbon dioxide concentrations has demonstrated, there are numerous fractures and sinkholes in the vicinity where deadly concentrations of this gas regularly occur [44. As the archaeological excavations in Hierapolis require the removal of a thick layer of travertine material that has accumulated over the centuries, much of the area of the ancient city still remains underground.

Unfortunately, the accounts of the early modern era travellers do not offer a complete picture and often quote the same ancient authors. Thus, it is even possible that the Plutonium discussed by Strabo was not the same place that was mentioned by Cassius Dio, as the latter author described the theatre above it, but Strabo did not. The earthquakes also added to the confusion, as the lack of activity of the deadly vapours, so much lamented by the travellers who wished to test them on innocent animals, could be explained by the closing and opening of various cracks and fissures in the ground. Yet again, there are not enough ancient materials to allow for the conclusive analysis of the chronology of Hierapolis earthquakes against the activation and deactivation of the Plutonia!

In the meantime, while visiting Hierapolis, one might hope that the newly discovered Plutonium will soon be open to visitors. When it happens, we will be able to see the replica of the marble statue of Hades and his threeheaded dog Kerberos that has recently been placed in its original setting. If the fresh whiteness of the copy is not what you expect then head to the Hierapolis Museum to say hello to the original statue of the underground overlord (see Figure 12).

\section{Summary}

In this paper, the long history of religious cults of Hierapolis in Phrygia has been described, with particular attention paid to the cult of Hades and its relation to other ancient deities. The connection between Anatolian and 


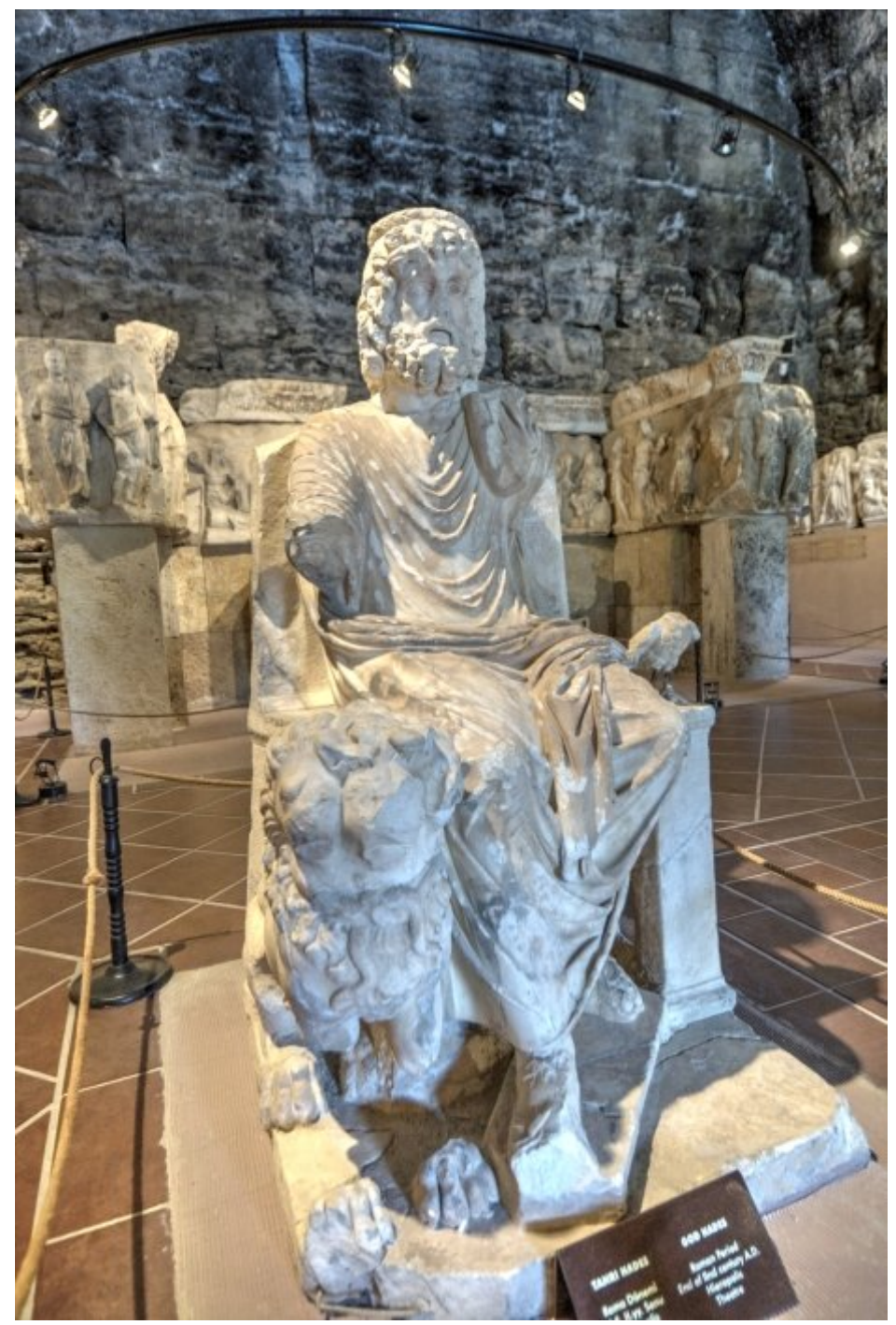

Figure 12: Hades and Kerberos statue, Roman period, the end of the 2nd century CE, Hierapolis Archaeological Museum, Turkey

Greek deities has also been discussed, and the connection between various personifications of Apollo and Hades has been presented, especially in relation to oracular and healing activities.

Moreover, the several ancient buildings of Hierapolis that performed religious functions have been described, including Apollo Temple and the unusual structure called the Plutonium. These descriptions have been supported by the ancient sources and the travelogues of early modern era authors.

Furthermore, these older descriptions have been compared and con- 
trasted with the results of modern scientific research conducted by historians and archaeologists and published in scientific journals. The recent findings made in the area of Hierapolis by the application of the latest technologies offer a promise of even more groundbreaking discoveries in the near future. Hopefully, they will shed more light on the still mysterious cult of Hades and its relation to the Apollo Temple.

\section{Appendix: Locations of the discussed places}

- Turkey

- Old Plutonium in Hierapolis: 37.92681,29.12686

- New Plutonium in Hierapolis: 37.92625,29.12704

- Temple of Apollo in Hierapolis: 37.926893, 29.126817

- Apollo Temple's Nymphaeum: 37.926863, 29.126385

- Akharaka: 37.9,28.1

- Sanctuary of Apollo Lairbenos: 38.214697, 29.280534

- Dionysopolis, modern-day Ortaköy: 38.173038, 29.301898 (probable location)

- Motella/Pulcherianopolis, modern-day Yeşiloba: 38.244787, 29.303311 (probable location)

- Thiounta: 38.110474,29.159451

- Claros: 38.005197, 27.192941

- Greece

- Nekromanteio Acheron (Cichyrus, Ephyra): 39.236189, 20.534149

- Elis: 37.89131,21.37493

- Eleusis: 38.041237, 23.538514

- Cape Tainaron: 36.386281, 22.482898

- Italy

- Mount Avernus and Kume (Cumae): 40.848611,14.053611

- Palazzo Altemps in Rome with the unique bust of Hades: 41.901155, 12.473056

\section{References}

[1] Evelyn-White, Hugh. The Homeric Hymns and Homerica with an English Translation. William Heinemann Ltd, London, 1914. 
[2] Godley, Alfred. The Histories of Herodotus. Harvard University Press, Cambridge, 1920.

[3] Jones, Horace. The Geography of Strabo. London Heinemann, London, 1917.

[4] Garth, Samuel and Dryden, John. Ovidius. Metamorphoses. 1717.

[5] Bostock, John. Pliny the Elder. The Natural History. Taylor and Francis, London, 1855.

[6] Jones, William and Ormerod, Henry. Pausanias. Description of Greece. William Heinemann Ltd, London, 1918.

[7] Cary, Earnest and Foster, Herbert. Cassius Dio. Roman History. The Loeb Classical Library. Harvard University Press, Cambridge, 1914.

[8] Rolfe, John. Ammianus Marcellinus. Roman History. The Loeb Classical Library. Harvard University Press, Cambridge, 1950. ISBN 9780674993310 .

[9] Asmus, Johann. Das Leben des Philosophen Isidoros von Damaskios. Verlag von Felix Meiner, Leipzig, 1911.

[10] Wheler, George. A Journey Into Greece. London, 1682.

[11] Spon, Jacob and Wheler, George. Voyage d'Italie, de Dalmatie, de Grèce et du Levant. Cellier, Lyon, 1678.

[12] Pococke, Richard. A description of the East, and some other countries. W. Bowyer, London, 1743.

[13] Smith, Thomas. Remarks upon the manners, religion and government of the Turks. Moses Pitt, London, 1678.

[14] Chandler, Richard. Travels in Asia Minor and Greece. Clarendon Press, Oxford, 1825.

[15] Leake, William. Journal of a tour in Asia Minor, with comparative remarks on the ancient and modern geography of that country. J. Murray, London, 1824.

[16] Cockerell, Charles. Travels in southern Europe and the Levant, 18101817. The journal of C.R. Cockerell. Longmans, Green, and Co., London, 1903.

[17] Laborde, Léon. Voyage de l'Asie mineure. Paris, 1838. 
[18] Arundell, Francis. Discoveries in Asia Minor, Including a Description of the Ruins of Several Ancient Cities, Especially Anitoch of Pisidia, vol. II. Richard Bentley, London, 1834.

[19] Texier, Charles. Description de l'Asie Mineure faite par ordre du gouvernement français de 1833 à 1837 et publiée par le ministère de l'Instruction publique. Paris, 1839.

[20] Fellows, Charles. A Journal written during an Excursion in Asia Minor. J. Murray, London, 1838.

[21] Davis, Edwin. Anatolica: Or, The Journal of a Visit to Some of the Ancient Ruined Cities of Caria, Phrygia, Lycia, and Pisidia. Grant \& Co., London, 1874.

[22] Choisy, Auguste. L'Asie Mineure et les Turcs en 1875: Souvenirs de Voyage par Auguste Choisy. Firmin-Didot, Paris, 1876.

[23] Humann, Carl, Cichorius, Conrad, Judeich, Walter, and Winter, Franz. Altertümer von Hierapolis. Georg Reimer, Berlin, 1898.

[24] Ramsay, William Mitchell. Artemis-Leto and Apollo-Lairbenos. The Journal of Hellenic Studies, vol. 10:216-230, 1889. doi:10.2307/623595.

[25] Ramsay, William Mitchell. The Cities and Bishoprics of Phrygia. Oxford, 1895.

[26] Bean, George. Turkey Beyond the Meander. The Classic guides to Turkey. John Murray Pubs Ltd, 1989. ISBN 978-0719546631.

[27] Bagnall, Roger, Brodersen, Kai, Champion, Craige, Erskine, Andrew, and Huebner, Sabine. The Encyclopedia of Ancient History. WileyBlackwell, 2012. ISBN 978-1405179355.

[28] Hjelde, Sigurd. Man, Meaning, and Mystery: 100 Years of History of Religions in Norway. the Heritage of W. Brede Kristensen, vol. 87 of Numen Books: Studies in the History of Religions. Brill, 2000. ISBN 978-9004114975.

[29] Brice, William. A Note on the Descent into the Plutonium at Hierapolis of Phrygia. Journal of Semitic Studies, vol. 23:226-227, 1978. doi: $10.1093 /$ jss $/ 23.2 .226$.

[30] Burton, Diana. Hades: Cornucopiae, Fertility And Death. In: 32nd Annual Conference of the Australasian Society for Classical Studies. Australasian Society for Classical Studies, Australasian Society for Classical Studies, Auckland, 2011. 
[31] Caskey, John and Dakaris, Sotirios. The dark palace of Hades. Archaeology, vol. 15:85-93, 1962.

[32] D'Andria, Francesco and Şimşek, Celal. Landscape and History in the Lykos Valley. Cambridge Scholars Publishing, 2017. ISBN 9781443898591 .

[33] Ferrero, Daria De Bernardi. Hierapolis. Marsilio, 1993.

[34] Fox, William. The Johns Hopkins Tabellae defixionum. Master's thesis, Johns Hopkins University, Baltimore, 1911.

[35] Grimal, Pierre. The Dictionary of Classical Mythology. Blackwell, Oxford, 1998. ISBN 9780631132097.

[36] Işın, Gül. The Cult of Apollo in Southern Pisidia and Apollo Sideton. Ege Üniversitesi Arkeoloji Dergisi Özel Sayı, vol. 12:107-117, 2008.

[37] Kerényi, Carl and Manheim, Ralph. Eleusis: Archetypal Image of Mother and Daughter, vol. 122 of Bollingen Series. Princeton University Press, 1991. ISBN 978-0691019154.

[38] Liritzis, Ioannis, Bousoulegka, Evgenia, Nyquist, Anne, Castro, Belen, Alotaibi, Fahad, and Drivaliari, Androniki. New evidence from archaeoastronomy on Apollo oracles and Apollo-Asclepius related cult. Journal of Cultural Heritage, vol. 26:129-143, 2017. doi:10.1016/j.culher.2017.02.011.

[39] Lorenzi, Rossella. Gate to Hell Found in Turkey. vol. 2018, 2013.

[40] Miller, Kevin. Apollo Lairbenos. Numen, vol. 32:46-70, 1985. doi: $10.2307 / 3269962$.

[41] Negri, Sergio and Leucci, Giovanni. Geophysical investigation of the temple of Apollo (Hierapolis, Turkey). Journal of archaeological science, vol. 33:1505-1513, 2006.

[42] Öztürk, Esengül and Tanriver, Cumhur. New katagraphai and dedications from the sanctuary of Apollon Lairbenos. Epigraphica Anatolica, p. $91-111,2008$.

[43] Wexler, Philip. History of Toxicology and Environmental Health: Toxicology in Antiquity, Volume I, vol. 1 of History of Toxicology and Environmental Health. Academic Press, 2014. ISBN 978-0128000458.

[44] Pfanz, Hardy, Yüce, Galip, Gulbay, Ahmet, and Gokgoz, Ali. Deadly CO 2 gases in the Plutonium of Hierapolis (Denizli, Turkey). Archaeological and Anthropological Sciences, p. 1-13, 2018. doi:10.1007/s12520-018-0599-5. 
[45] Howgego, Christopher, Heuchert, Volker, and Burnett, Andrew. Coinage and Identity in the Roman Provinces. Oxford University Press, Oxford, 2005. ISBN 978-0199265268.

[46] Rupke, Jorg. A Companion to Roman Religion. Blackwell Companions to the Ancient World. Wiley-Blackwell, 2011. ISBN 978-1444339246.

[47] Sparavigna, Amelia. The Temple of Apollo Lairbenos in Hierapolis and its Orientation to the Sunrise on Summer Solstice. 2018.

[48] Stewart, Iain and Piccardi, Luigi. Seismic faults and sacred sanctuaries in Aegean antiquity. Proceedings of the Geologists' Association, vol. 128:711-721, 2017. doi:10.1016/j.pgeola.2017.07.009.

[49] Stillwell, Richard. The Princeton encyclopedia of classical sites, vol. 4916. Princeton University Press, 2017.

[50] Tsagalis, Christos. Inscribing sorrow: fourth-century Attic funerary epigrams, vol. 1. Walter De Gruyter, 2008. ISBN 978-3110201321.

[51] Wilson, Mark. Biblical Turkey. Ege Yayınları, Istanbul, 2012. ISBN 978-605-5607-90-6.

[52] Brenk, Frederick. Relighting the Souls: Studies in Plutarch, in Greek Literature, Religion, and Philosophy, and in the New Testament Background. Franz Steiner Verlag, 1998. ISBN 978-3515071581.

[53] Sear, Frank. Roman theatres: an architectural study. Oxford University Press, 2006. 